\title{
Snow precipitation at four ice core sites in East Antarctica: provenance, seasonality and blocking factors
}

\author{
Claudio Scarchilli · Massimo Frezzotti • \\ Paolo Michele Ruti
}

Received: 27 April 2010/Accepted: 11 November 2010/Published online: 3 December 2010

(C) Springer-Verlag 2010

\begin{abstract}
Snow precipitation is the primary mass input to the Antarctic ice sheet and is one of the most direct climatic indicators, with important implications for paleoclimatic reconstruction from ice cores. Provenance of precipitation and the dynamic conditions that force these precipitation events at four deep ice core sites (Dome C, Law Dome, Talos Dome, and Taylor Dome) in East Antarctica were analysed with air mass back trajectories calculated using the Lagrangian model and the mean composite data for precipitation, geopotential height and wind speed field data from the European Centre for Medium Range Weather Forecast from 1980 to 2001. On an annual basis, back trajectories showed that the AtlanticIndian and Ross-Pacific Oceans were the main provenances of precipitation in Wilkes Land (80\%) and Victoria Land $(40 \%)$, respectively, whereas the greatest influence of the ice sheet was on the interior near the Vostok site (80\%) and in the Southwest Ross Sea (50\%), an effect that decreased towards the coast and along the Antarctic slope. Victoria Land received snowfall atypically with respect to other Antarctica areas in terms of pathway (eastern instead of western), seasonality (summer instead of winter) and velocity (old air age). Geopotential height patterns at $500 \mathrm{hPa}$ at low (>10 days) and high (2-6 days) frequencies during snowfall cycles at two core sites showed large positive anomalies at low frequencies developing in the Tasman Sea-Eastern Indian Ocean at higher latitudes $\left(60-70^{\circ} \mathrm{S}\right)$ than normal. This could be considered part of an
\end{abstract}

C. Scarchilli · M. Frezzotti $(\bowtie) \cdot$ P. M. Ruti

ENEA, Rome, Italy

e-mail: massimo.frezzotti@enea.it

C. Scarchilli

Università degli studi di Trieste, Trieste, Italy atmospheric blocking event, with transient eddies acting to decelerate westerlies in a split region area and accelerate the flow on the flanks of the low-frequency positive anomalies.

Keywords Precipitation - Surface mass balance . Blocking high $\cdot$ Southern hemisphere dynamic

\section{Introduction}

Polar ice sheets are valuable archives of paleoclimate information, and deep ice cores have been drilled at several locations in the Antarctic and Greenland ice sheets. Ice core records provide a cornucopia of information about past climates, environments and atmospheric circulation (Barbante et al. 2010). These records, currently spanning the last 800,000 years (Jouzel et al. 2007), are key to the identification of the causes and forcing mechanisms of climate change. Ice cores are also especially valuable in remote areas such as Antarctica, where long-term observations or historical records are scarce and inadequate (Turner et al. 2005). The climate record derived from wet deposition in ice cores is determined mainly by the conditions that prevail when snow precipitation occurs and from post-deposition processes, such as wind-borne redistribution and surface and snowdrift sublimation (Frezzotti et al. 2007; Scarchilli et al. 2010). However, several factors, including the seasonality of snow precipitation and changes in moisture sources and pathway regions, may bias the interpretation of the ice record (e.g. Jouzel et al. 2003; Schlosser et al. 2008; Sime et al. 2009). An understanding of Antarctic snow accumulation is therefore necessary to determine the present state of the ice sheet and to make predictions regarding its potential contribution to rising sea 
levels. Moreover, recent studies conducted for Dome $\mathrm{C}$ and the Talos Dome suggested that the pathway of precipitation could induce local spatial and temporal accumulation changes and induce migration of dome summits, even at decadal to centennial scales (Urbini et al. 2008). Various studies have estimated the moisture flux and moisture sources at ice core sites in Antarctica using General Circulation Models (e.g. Delaygue et al. 2000; Werner et al. 2001; Noone and Simmonds 2002) isotopic model (e.g. Ciais and Jouzel 1994; Delmotte et al. 2000) or trajectory model and global numerical meteorological reanalysis data sets (e.g. Noone et al. 1999; Suzuki et al. 2008; Reijmer et al. 2002; Thomas and Bracegirdle 2009; Helsen et al. 2007; Sodemann and Stohl 2009).

In the Southern Hemisphere (SH), the absence of a pattern of mountain chains that locks the phase of planetary scale waves implies that most of the atmospheric variability is accounted for by eastwardly propagating wave trains at both high and low frequencies (Dell' Aquila et al. 2007). High frequencies roughly correspond to periods shorter than 10 days, where the mid-latitude atmospheric flow is dominated in both hemispheres by the growth and decay of baroclinic disturbances (Dell'Aquila et al. 2007), which convert available potential energy into kinetic energy. In the $\mathrm{SH}$, for comparison, the baroclinic activity is stronger than in the Northern Hemisphere (NH) and peaks around $50^{\circ} \mathrm{S}$. Regionally, the high-frequency disturbances are strongest in the southern Indian Ocean (Trenberth 1991; Frederiksen and Frederiksen 1993; Cuff and Cai 1995), where the meridional heat fluxes are maximal. On the low-frequency time-scale (10-50 days), the eastwardly propagating waves trains feature a characteristic spatial pattern, often referred to as the Pacific South American (PSA) pattern, characterised by ultra-long spatial scales (Robertson and Mechoso 2003). A standing pattern associated with spatial zonal wavenumber 3 and often related to blocking events is also present in this location (Trenberth and Mo 1985; Dell'Aquila et al. 2007). Therefore, the study of how the signals of regional and global climate variability are registered into the ice core record through the calibration of climate proxies with ECMWF (European Centre for Medium Range Weather Forecast) re-analysis is very important to derive information on paleo-atmospheric circulation and surface mass balance from ice cores.

In the context of the European drilling project led by Italy, called TALDICE (TAlos Dome Ice CorE, http://www.taldice.org), a new 1,620 m deep drilling was carried out at Talos Dome. This is a peripheral dome at the junction between the East Antarctic Plateau and the Transantarctic Mountains along the western coast of the Ross Sea (Frezzotti et al. 2004; Stenni et al. 2010). The TALDICE ice core provides a paleoclimate record covering at least 250,000 years, dating back to Marine Isotope Stage
7.5 (Stenni et al. 2010). The Talos Dome has good geochemical and paleoclimate records preserved in ice because the accumulation at this site ( $80 \mathrm{~mm}$ water equivalent (w.e.) year $^{-1}$ ) is higher than at other inland domes in East Antarctica (Frezzotti et al. 2004, 2007; Stenni et al. 2002). The results obtained at the Talos Dome will therefore complement, verify, and augment the paleorecords collected at the "near-coastal sites" of EPICA-DML, Berkner Island, Taylor Dome, Siple Dome and Law Dome and at other Antarctic deep-drilling sites (EPICA-Dome C, Vostok, and Dome Fuji). As such, this polar record of climate forcing and responses would represent a significant contribution to the International Partnerships in Ice Core Sciences 40,000-year network (http://www.pages-igbp.org/ipics/).

In this study, the provenance, the spatial gradient and the dynamic conditions that forced precipitation events over the East Antarctic Ice Sheet were analysed, combining a Lagrangian trajectory model (Hybrid Single-Particle Lagrangian Integrated Trajectory) output and the European Re-Analysis ERA40 (from 1980 to 2001) data (Uppala et al. 2005) obtained from the European Centre for Medium Range Weather Forecast (ECMWF). Then we used a similar approach to discuss the resulting characteristic seasonal variations of air transport routes that carried snow precipitation to Talos Dome and adjacent deep ice cores Dome C, Law Dome, and Taylor Dome. Moreover, we have improved our understanding of the role of atmospheric geopotential anomalies in poleward moisture transport. However, the processes that control climate, how it evolves and its inter-annual variability and comparison with ice core time series are the subjects of other manuscripts in preparation.

In Sect. 2, we review the main regions on which our analysis concentrated, describe the considered datasets, and present the dynamical-statistical methods (back-trajectories model and low-high frequency decomposition techniques). In Sect. 3, we show the results of snowfall-related back trajectories and discuss the emerging differences. In Sect. 4 , we analyse the synoptic features related to snowfall, and in Sect. 5, we discuss the results obtained. Finally, in Sect. 6 , we present our conclusions and outlook for future studies.

\section{Data and methods}

\subsection{Study regions}

Our analysis concentrated on three contrasting regions of East Antarctica $\left(90^{\circ}-180^{\circ} \mathrm{E}\right.$ and $\left.65^{\circ}-80^{\circ} \mathrm{S}\right)$, the high Plateau (Dome C), the Southern Indian Ocean (Law Dome and Talos Dome) and the Ross Sea (Taylor Dome and Talos Dome), as outlined in Fig. 1. 


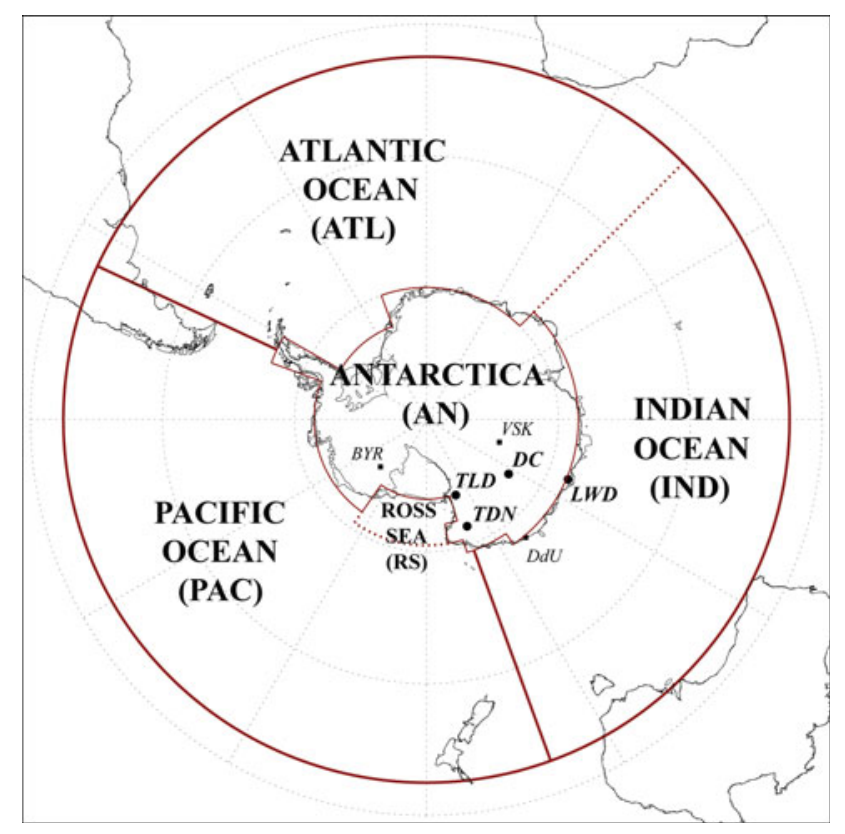

Fig. 1 Map of Southern Hemisphere with the Pacific Ocean (PAC), Indian Ocean (IND), Atlantic Ocean (ATL) and Antarctica (AN) boundaries (red line) shown; Dome C (DC), Law Dome (LWD), Taylor Dome (TLD) and Talos Dome (TDN) sites (filled, large dark point) and Dumont D'Urville (DdU), Vostok (VSK) and Byrd (BYR) sites (filled, small dark square) are also shown

The Talos Dome (TDN) is a peripheral dome, approximately $30 \times 30 \mathrm{~km}$ in size, that is located approximately $290 \mathrm{~km}$ from the Southern Ocean, $250 \mathrm{~km}$ from the Ross Sea, $275 \mathrm{~km}$ from the Zucchelli Station (Terra Nova Bay), $1,100 \mathrm{~km}$ east of Dome C, 1,900 km E-SE from Law Dome, and $550 \mathrm{~km}$ north of Taylor Dome (Fig. 1; Table 1). The Talos Dome surface contour lines are elliptical and elongated in a NW-SE direction. The elongation direction of the dome is perpendicular to the prevalent wind direction (Urbini et al. 2008).

The Law Dome (LWD) is an ice cap (200 km in diameter) neighbouring the coastal edge of the southern Indian Ocean of the main East Antarctic Ice Sheet (Morgan et al. 1997). The LWD regional climate is strongly influenced by cyclonic precipitation and shows a strong maritime signature (Masson-Delmotte et al. 2003) with links to lower latitudes (McMorrow et al. 2002). The core site is located near the summit, approximately $100 \mathrm{~km}$ from the sea, at an elevation of $1,370 \mathrm{~m}$ (Morgan et al. 1997). The high accumulation and moderate ice thickness allow extended Holocene Records and the Last Glacial Maximum transition to be located close to the bedrock.

In December 2004, a 3,270-m-deep ice core was recovered at Dome C (DC) close to the French-Italian Concordia Station, within the framework of EPICA (European Project for Ice Coring in Antarctica). This core provided the oldest existing ice climate record, extending to approximately 800,000 years ago (Jouzel et al. 2007). DC, Antarctica's fourth highest dome $(3,233 \mathrm{~m})$, is situated approximately $1,000 \mathrm{~km}$ from the southern Indian Ocean and the Ross Sea. The DC surface is an elliptical shape $(50 \times 35 \mathrm{~km})$ with its minor axis $(\mathrm{NW}-\mathrm{SE})$ approximately $70 \%$ shorter than its major (SW-NE) axis; the elongation direction of the dome is parallel to the prevalent SW-NE wind direction (Urbini et al. 2008).

Taylor Dome (TLD) is a near-coastal (approximately $120 \mathrm{~km}$ ) East Antarctic site at the south-western edge of the Ross Sea. TLD is a local snow accumulation area at the edge of the East Antarctic Plateau at the boundary between the Plateau and the Dry Valleys. It is a ridge approximately $20 \times 80 \mathrm{~km}$ in size, located just inland of the Transantarctic Mountains, and provides ice to outlet glaciers entering Taylor Valley and McMurdo Sound. The TLD ice core provided a record through the entire last glacial cycle Marine Isotope Stage 6 (130,000 years; Steig et al. 2000).

\subsection{Data}

Figure 2 shows a general outline of the approach and data used in this paper. Antarctic precipitation (SF) was evaluated through the ECMWF ERA 40 reanalysis data fields with a regular $1.125^{\circ} \times 1.125^{\circ}$ grid (Fig. $2 \mathrm{a}$ ). The $+24-\mathrm{h}$ forecast field was used because the ERA40 precipitation forecast at less than $24 \mathrm{~h}$ at the surface of the ice sheets was more strongly affected by spin-up problems (Bromwich et al. 2002), and the error became larger on the interior Plateau (Genthon 2002). Moreover, Tietäväinen and Vihma (2008) showed that the annual net precipitation from a 6-h forecast was approximately $10 \%$ smaller than that from a 24-h forecast.

Although the ERA 40 dataset covered the time period from 1958 to 2002, the analysis used in this paper covered only the period from 1980 to 2001 . This choice was made because of possible inconsistencies in reanalysis before 1979, which were correlated with the absence (e.g. sea ice coverage data) or changes in the volume and type of data available for model initialisation in the pre-satellite era (Bromwich et al. 2007). The ERA 40 snowfall field was able to reproduce inter-annual spatial accumulation variability and trends, especially where post-depositional effects did not strongly affect accumulation (Monaghan et al. 2006). Comparisons of ECMWF data with automatic weather station and annual ice core records have demonstrated that ECMWF data captured a large proportion of annual and sub-seasonal precipitation variability at the ice core site (Thomas and Bracegirdle 2009) in the Antarctic Peninsula. However, these data over the Plateau region should be considered with care due to the excessively dry conditions forecast for the winter from the lack of "diamond dust" or "clear sky" precipitation parameterisation 
Table 1 Geographical and climatological characteristics of the four starting points for the back trajectory calculations (Fig. 1)

\begin{tabular}{|c|c|c|c|c|c|c|c|c|}
\hline Core site & Lat. S & Long. E & $\begin{array}{l}\text { Elevation } \\
(\mathrm{m})\end{array}$ & $\begin{array}{l}\text { Distance } \\
\text { from coast } \\
(\mathrm{km})\end{array}$ & $\begin{array}{l}\text { Distance from } \\
\text { winter sea ice } \\
\text { limit }(\mathrm{km})\end{array}$ & $\begin{array}{l}\text { Snow accumulation } \\
\left(\mathrm{mm} \text { w.e. year }{ }^{-1} \text { ) }\right. \\
\text { (period) }\end{array}$ & $\begin{array}{l}\text { Snow precipitation } \\
\text { from ERA } 401980-2000 \\
\left(\mathrm{~mm} \text { w.e. year }{ }^{-1} \pm \mathrm{SD}\right)\end{array}$ & $\begin{array}{l}\text { Temp. } \\
\left({ }^{\circ} \mathrm{C}\right)\end{array}$ \\
\hline Dome C & $75^{\circ} 06^{\prime}$ & $123^{\circ} 21^{\prime}$ & 3,233 & 920 & 1,150 & $28.3 \pm 2.4^{*}(1966-2001)$ & $17 \pm 3$ & $-54.5^{*}$ \\
\hline Law Dome & $66^{\circ} 46^{\prime}$ & $112^{\circ} 48^{\prime}$ & 1,390 & 100 & 250 & $\sim 650^{\wedge}$ (last 50 years) & $565 \pm 80$ & $-21.8^{\wedge}$ \\
\hline Talos Dome & $75^{\circ} 49^{\prime}$ & $159^{\circ} 11^{\prime}$ & 2,315 & 250 & 900 & $87 \pm 8^{\circ}(1966-1996)$ & $75 \pm 15$ & $-41^{\circ}$ \\
\hline Taylor Dome & $77^{\circ} 48^{\prime}$ & $158^{\circ} 43^{\prime}$ & 2,365 & 120 & 1,600 & $67 \pm 7^{\#}(1964-1990 \mathrm{~s})$ & $54 \pm 17$ & $-43^{\#}$ \\
\hline
\end{tabular}

* Frezzotti et al. (2005)

$\wedge$ Morgan et al. (1997)

- Stenni et al. (2002)

\# Morse et al. (1999)

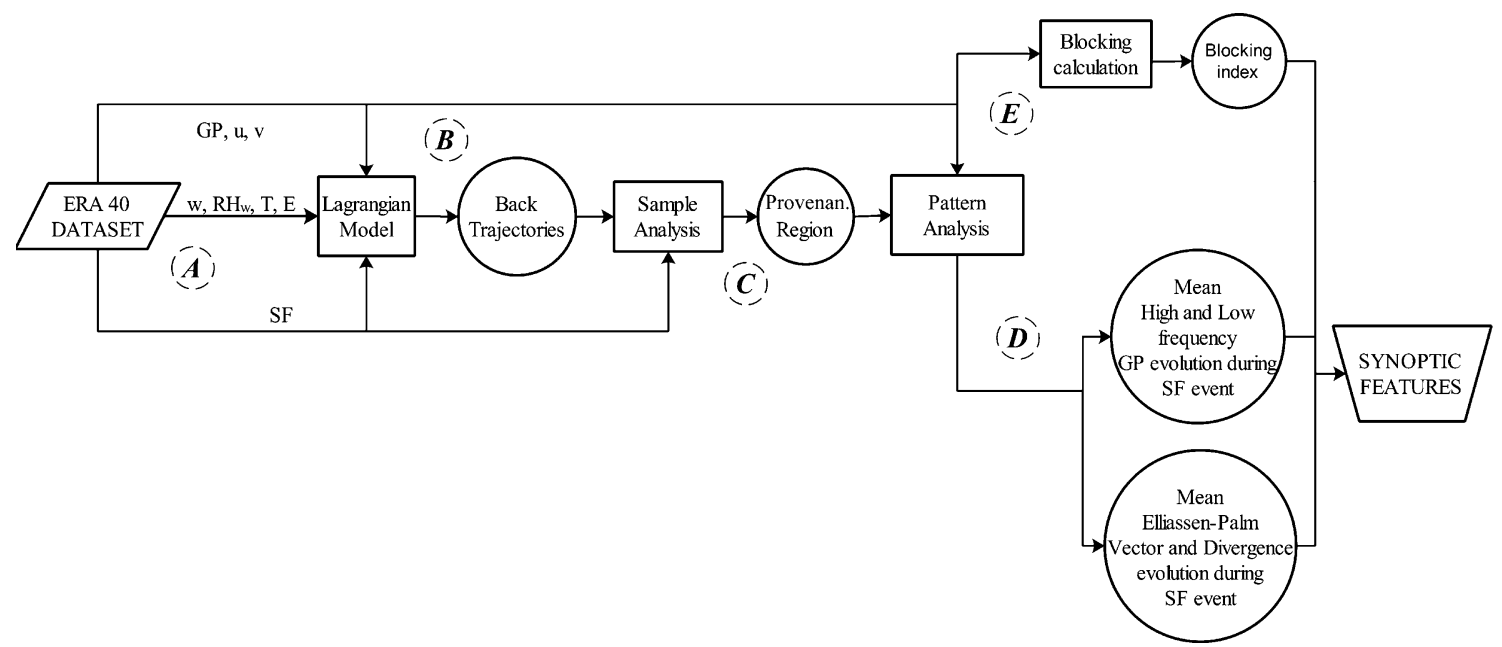

Fig. 2 Schematic outline of the experimental approach. Bold letters (a-e) represent the five steps discussed in the text

in the model reanalysis (Reijmer et al. 2002; Monaghan et al. 2006; van de Berg et al. 2006) and the excessively enhanced precipitation during the summer (Helsen et al. 2007). Regardless, a comparison with limited in situ observations from the DC area suggested that ECMWF estimates of daily precipitation totals were reasonably accurate (Massom et al. 2004). However, the comparison between field measurements and model outputs is not straight onward, because: (1) snow accumulation in Antarctica is mainly the sum of precipitation minus winddriven erosion processes (Eisen et al. 2008; Frezzotti et al. 2007); (2) there are systematic differences in the scale of observations and model outputs (core site in decimetres and ERA40 grid in hundreds of $\mathrm{km}$ ).

The vertical and horizontal wind components $(\mathrm{u}, \mathrm{v}$, and w), relative humidity with respect to water $\left(R H_{w}\right)$, temperature ( $T$ ) and geopotential fields (GP) from the ERA 40 reanalysis at the surface and at 23 pressure levels for the synoptic hours $(00,06,12,18 \mathrm{UTC})$ with a $2.5^{\circ} \times 2.5^{\circ}$ regular grid were used as the back-trajectory model inputs.
The u, v and GP fields at 300 and $500 \mathrm{hPa}$ were also used to describe the synoptic conditions during snowfall events and to construct an index correlated with blocking high conditions in the lower troposphere.

\subsection{Back-trajectories model}

The HYSPLIT Lagrangian model, developed by NOAA and Australia's Bureau of Meteorology (Draxler 2003), was used to calculate air mass back trajectories (Fig. 2b). Five-day back trajectories were computed daily from January 1,1980 , to December 31,2001 , arriving at 12 UTC and $3000 \mathrm{~m}$ over each point of a $2.5^{\circ} \times 2.5^{\circ}$ regular grid spanning from $85^{\circ} \mathrm{S}, 175^{\circ} \mathrm{E}$ and $60^{\circ} \mathrm{S}, 90^{\circ} \mathrm{E}$ and over the four studied drill sites to include the entire area over Victoria Land and Wilkes Land. Each Back Trajectory (TJ) was projected onto the SF forecast field, and the nearest model value was associated with hourly precipitation along the trajectory path, assuming a constant precipitation rate during the day. 
Uncertainties in the resulting trajectories were caused by both numerical truncations in the calculation algorithm and resolution errors due to the limited resolution of the meteorological dataset in space. It was possible to estimate the total error on the order of $1,500 \mathrm{~km}$ after 5 days (15-30\% of the travel distance). This high value was probably due to the coarse grid of the meteorological model data used; however, other studies (Stohl et al. 1995; Kottmeier and Fay 1998; Suzuki et al. 2008) calculated trajectories over the Antarctic using different Lagrangian models with (generally) higher horizontal grid resolution, and the corresponding errors were only slightly lower than those computed in this work.

\subsection{Pathway and source regions analysis}

The regions of air masses connected to SF events were identified by two different sample analyses (Fig. 2c), both based on the division of the Southern hemisphere into five grid cells (Fig. 1): Antarctica (AN), Atlantic Ocean (ATL $70^{\circ} \mathrm{W}-45^{\circ} \mathrm{E}$ ), Indian Ocean (IND $45^{\circ} \mathrm{E}-160^{\circ} \mathrm{E}$ ), Ross Sea (RS) and Pacific Ocean (PAC $\left.160^{\circ} \mathrm{E}-70^{\circ} \mathrm{W}\right)$. In the first analysis, where the East Antarctica area $\left(85^{\circ} \mathrm{S}, 175^{\circ} \mathrm{E}\right.$ and $60^{\circ} \mathrm{S}, 90^{\circ} \mathrm{E}$ ) was studied, the most important air mass source sector was defined as the one where the TJ spent the majority of their time. In the second analysis, where the provenance of snow precipitation over the four distinct drill sites (Law Dome, Dome C, Talos Dome, and Taylor Dome) was analysed, a division through a k-mean cluster analysis (Everitt 1993) was preferred. In this case, a selected number of TJ were divided into groups (CL) through cluster analysis based on air parcel path longitude, latitude and height over the terrain. The selection took into account only TJ related to snowfall events starting from sea sectors (RS+PAC and IND+ATL) and lying over a sea sector for most of the five-day period to consider only consistent events. The cluster method avoided dependence on the subjectivity of the sea sector boundaries. In fact, the choice of cluster number was almost subjective, but tests for each site with different cluster numbers did not give improved results. Moreover, Sodemann and Stohl (2009) identified the long-range moisture transport in Antarctica (20 days prior) with the trajectory model output FLEXPART (Stohl et al. 2005) pointing out that the highest altitudes of East Antarctica have the mean source latitudes at $45-40^{\circ} \mathrm{S}$ year-round and a five-day backward trajectory was insufficient to reveal the complete source of moisture because it provided moisture source that accounted for only $50 \%$ of the total precipitation, whereas a 10-day period provided a source of moisture for approximately $80 \%$. However, there was an increasing degree of uncertainty for longer trajectories respect to 5-day back trajec- tory. Our results were perfectly in agreement with the pathway of long-range moisture advection. In this study, we primarily analysed the pathway or provenance of the last 5 days of moisture sources, looking specifically at the longitudinal location or southern ocean sector of these sources.

\subsection{Eliassen-Palm vectors, time series constructions}

The synoptic activity and local interaction between transient eddies and mean flow during snowfall events at drill sites were studied with composite map time series (MPts) of low- and high-pass filtered GP deviation from zonal means at $500 \mathrm{hPa}$ and with the Eliassen-Palm flux vector $\left(\mathrm{E}_{\mathrm{u}}\right)$ (Fig. 2d). The field data were high-pass filtered using a filter (hereafter referred to as the 2-6-day filter) with seven weights, with the response equal to unity for waves shorter than 4 days and with the half-power point at the 6.4 days period (Trenberth 1986). On the other hand, the low-pass filter was obtained in a Fourier transformation by retaining only frequencies with a period greater than 10 days. The 10 days threshold choice was based on the analysis of the $\mathrm{SH}$ low- and high-frequency atmospheric variability performed by Dell' Aquila et al. (2007).

The E-P flux vector was evaluated at $300 \mathrm{hPa}$ according to the formulation of Trenberth (1986):

$E_{u}=\left[\frac{1}{2}\left(\overline{v^{\prime 2}}-\overline{u^{\prime 2}}\right),-\overline{v^{\prime} u^{\prime}},-\left(\frac{f}{\sigma} \overline{v^{\prime} T^{\prime}}+\overline{u^{\prime} w^{\prime}}\right)\right] \cos (\phi)$

where $\overline{()}$ denotes a time mean, ()$^{\prime}$ is a deviation from the time mean, and $\phi$, f and $\sigma$ are the latitude, the Coriolis parameter and the static stability, respectively. The divergence (or convergence) of the $\mathrm{E}_{\mathrm{u}}$ vector $\left(\nabla \cdot E_{u}\right)$ corresponded to a forcing of the mean horizontal circulation that tended to increase (or decrease) with westerly flow. For meridionally elongated eddies, the vector points eastward along the minor axis, while for zonally elongated eddies, it points westward along the major axis.

The map time series MPts was defined for each CL cluster sample:

$\operatorname{MPts}_{C L}^{X}=\bar{X}_{t-n} \ldots, \bar{X}_{t-1}, \bar{X}_{t}, \bar{X}_{t+1}, \ldots \bar{X}_{t+n}$

where $\bar{X}_{t}$ is the average of all daily values assumed by the variable $X$ at day $t$ during the snowfall events associated with back trajectories included in the cluster CL, and $\bar{X}_{t \pm n}$ is the mean of the values assumed by the variable $n$ days before or after the events at time t. The MPts were calculated from 6 days before the event to 5 days after the event, and they describe the mean evolution cycle of large-scale dynamic features correlated with snowfall in East Antarctica. 


\subsection{Blocking index}

The atmospheric blocking index was calculated (Fig. 2e) with the GP data at $500 \mathrm{hPa}$ using the methodology described in Tibaldi et al. (1995) (referred to as TMR hereafter). The TMR method defines a local blocking index for each longitude if one of the following conditions is satisfied:

1) There is a persistent breakdown in the zonal wind at mid-to-high latitudes, as in Tibaldi et al. (1994), and the anomaly in the GP field at $60^{\circ} \mathrm{S}$ with respect to the long-term annual mean $\left(\mathrm{GP}_{A N O M}\right)$ is greater than $30 \mathrm{~m}$.

2) The $\mathrm{GP}_{\text {ANOM }}$ is greater than $150 \mathrm{~m}$.

The statement over $\mathrm{GP}_{A N O M}$ in the first condition reinforces the ability of the procedure, presented in Tibaldi et al. (1994), to discharge of an intense cut-off low, sometimes identified as a block. Meanwhile, the second condition allows the identification of the anomalous block displaced to the South. The $150 \mathrm{~m}$ threshold limit was chosen following Dole's (1986) definition of persistent positive anomalies during blocking conditions.

Introducing the fictitious concept of a $20^{\circ}$ longitudewide spatial sector, a sector was defined as blocked if at least three consecutive longitudes that were contained in it were blocked at the same time. This spatial filter allowed for the disregard of blocking-like features that did not fulfil spatial extension requirements. The sector-blocking index was controlled following the time requirement described in Marques and Rao (2000) and D'Andrea et al. (1998) to avoid spurious sector index failure. Finally, a time filter, excluding each blocking episode lasting less than 5 days, was applied to ensure that a true synoptic blocking episode would be persistent in time.

A sensibility test on the TMR calculation demonstrated a decrease in the annual blocking index frequency value up to $40 \%$ using a height threshold limit on $\mathrm{GP}_{\text {ANOM }}$ of $200 \mathrm{~m}$ (rather than $150 \mathrm{~m}$ ) and a decrease of up to $10 \%$ with a time filter of 6 days (rather than 5 days) for the blocking event length.

Finally precipitation statistics related to blocking condition at each site, discussed in paragraph 5, are calculated with precipitation event lasting the same day or the day before the longitudinal spatial sector $120^{\circ} \mathrm{E}-180^{\circ} \mathrm{E}, 180^{\circ} \mathrm{W}-120^{\circ} \mathrm{W}$, $120^{\circ} \mathrm{W}-60^{\circ} \mathrm{W}$ for $\mathrm{LWD} / \mathrm{DC}$, TDN and TLD, respectively resulted blocked through the TMR methodology.

\section{Snowfall-related back trajectories}

\subsection{Snowfall climatology}

The mean annual SF field along the $90^{\circ} \mathrm{E}-180^{\circ} \mathrm{E}$ sector (Fig. 3a) illustrated that the main precipitation occurred along the Wilkes Land coast, with an annual mean maximum above $600 \mathrm{~mm}$ w.e. between Dumont D'Urville (DdU, 66 ${ }^{\circ} 40^{\prime} \mathrm{S} 140^{\circ} \mathrm{E}$ ) and LWD, with lower values along the western Ross Sea coast. The mean SF decreased over the East Antarctic Plateau with values less than $20 \mathrm{~mm}$ w.e. year ${ }^{-1}$ in an area covering the Vostok (VSK, $79^{\circ} 27^{\prime} \mathrm{S}$ $106^{\circ} 50^{\prime} \mathrm{E}$ ) and DC sites because most of the large weather systems did not have the kinetic energy necessary to pass the steep orography of coastal area and penetrate inland (King and Turner 1997). The Ross Sea area showed values from 70 to $150 \mathrm{~mm}$ w.e. year ${ }^{-1}$ and a larger SF decrease towards the Plateau region with respect to Wilkes Land due to a steeper slope variation. These observations were in line with previous results from an atmospheric model (van de Berg et al. 2006; Monaghan et al. 2006).

The tropospheric circulation along the Wilkes Land coast was dominated by the circumpolar trough (CPT), with a spatial minimum on mean sea level pressure near $90^{\circ} \mathrm{E}$ (King and Turner 1997). The major portion of the precipitation in Wilkes Land was thought to occur in the maritime air masses on the eastern flank of the vortex centre as they moved poleward and underwent orographic lifting over the steep slope (Bromwich 1988). Intermittent blocking-anticyclone events in the South Tasman Sea caused significant precipitation events in Wilkes Land by conveying warm and moist air masses deep into the continental interior, thousands of kilometres to the southwest (Goodwin et al. 2003; Massom et al. 2004). In addition, Carrasco et al. (2003) analysed the distribution and characteristics of mesoscale cyclones in the area from the Ross Sea to the Weddell Sea and reported that the average diameter of the mesoscale vortices was smaller (50\%) and more frequently found (6 times) in the western Ross Sea sector than in the southern Ocean area (Bellingshausen and Weddell Seas). During the winter season, mesoscale cyclones in the Ross Sea were characterised by a lack of moisture, due to the Ross Ice Shelf and the extensive presence of sea ice that inhibited cloud formation. Moreover, SF seasonal variations are apparent in Fig. 3b, c, where SF decreased over Wilkes Land with an elongated and smoothed maximum along the coastline but then increased over the Ross Sea area in the summer (DJF). On the other hand, an inversion of this tendency was clear during the winter (JJA), with a decrease over the Ross area and an increase over the Wilkes Land coasts (Fig. 3d).

\subsection{Snowfall-related back trajectories in East Antarctica}

The results of the sample analysis for the entire area comprising all the TJ starting points are reported in Fig. 3, where the annual and seasonal mean percentages of TJ related to snowfall in a sector during most of the 5-day 
Fig. 3 Composite contour of the cumulative value of ECMWF +24-h forecast snowfall (filled contour) and percentages of snowfall (yellow, red and green contour) related to the 5-day trajectories, which spent the greatest part of their path above either the Pacific Ocean and Ross Sea (yellow lines), the Indian and Atlantic Oceans (red lines) or the continent (green lines). a annual average, $\mathbf{b}$ summer, $\mathbf{c}$ winter and d difference between winter and summer. Note the different sampling between negative (each $5 \mathrm{~mm}$ w.e) and positive values (each $10 \mathrm{~mm}$ w.e) in the colour bar

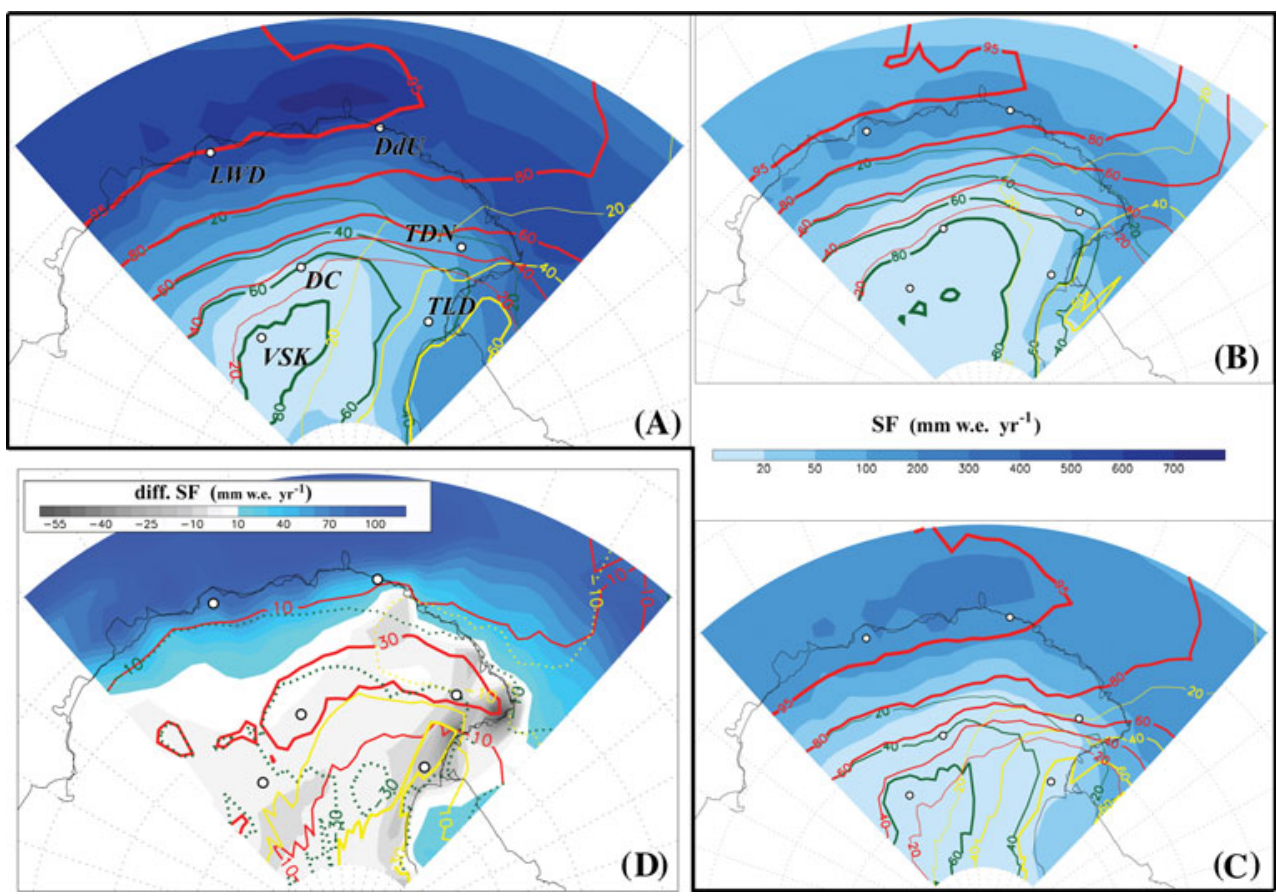

period are shown. The IND+ATL sector exerted its influence mainly along the entire Wilkes land area and, to a lesser extent, over the northern Victoria Land area, which correlated with the frequent eastward passage of synopticscale weather systems and associated cloud bands within the CPT. Additionally, TJ percentages up to $95 \%$ were calculated for coastal sites, such as DdU and LWD, and for areas of absolute SF maxima offshore of Adelie Land (Fig. 3a). However, decreases were found towards the Plateau region, with $40 \%$ contour line brush areas with $\mathrm{SF}<20 \mathrm{~mm}$ year $^{-1}$ and an annual average value of 30 and $15 \%$ for the DC and VSK sites, respectively. The influence of RS + PAC sectors extended mostly over the $150^{\circ}-180^{\circ} \mathrm{E}$ longitudinal arch, with a $60 \%$ core over the western Ross Sea and stretching to the Terra Nova Bay. SF from RS+PAC declined radially inland, with values over high Plateau regions of $10 \%$, and northward over Victoria Land, with a value of $30 \%$ at the TDN site. Finally, the AN sector's main impact was in the highest part of East Antarctica over the VSK and DC areas, with values of 80 and $60 \%$, respectively, while its influence decreased towards northern Victoria Land, where all three sectors had approximately the same impact.

In the winter, the deepest parts of the CPT trough were found around most of East Antarctica and in the eastern part of the Ross Sea, and significant cyclogenesis occurred in the Indian Ocean (Simmonds et al. 2003). Consequently, the IND+ATL sector greatly increases its strength, developing $\mathrm{TJ}$ that were able to intrude towards the Plateau region past the VSK site, resulting in a $10 \%$ enhancement at that site with respect to the annual mean
(Fig. 3c). During the spring, a slow contraction of the IND+ATL influence field began, which was correlated with a decrease in CPT intensity along the East Antarctic coast, reaching its maximum in the summer (Fig. 3b), when most of the high Plateau and Victoria Land areas had values below $20 \%$. At the same time, a decrease of $20 \%$ occurred at the TDN site (Fig. 3d). Conversely, the Plateau sector expanded (decreased) its field through the spring (fall), reaching the upper (lower) limit of expansion and area covered by its core during summer (winter). The behaviour of RS + PAC field differed and reached maximum expansion in summer, growing $20 \%$ over northern Victoria Land and eastern Wilkes Land between TDN and DdU, although its core decreased its areal extension by $60 \%$, becoming completely embedded in the Ross Sea (Fig. 3c).

\subsection{Snowfall back trajectories at the core site}

The pathways of precipitation at the four drilling sites were analysed using cluster analyses of snowfall trajectory. The cluster analysis was based on TJ fulfilling conditions that were described in Sect. 2.4. As its best result, it achieved four clusters $\left(C L_{I N D 1}^{T D N}, C L_{I N D 2}^{T D N}, C L_{R O S S}^{T D N}\right.$ and $\left.C L_{P A C}^{T D N}\right)$ for the TDN site and two clusters $\left(C L_{I N D}^{D C}, C L_{P A C}^{D C} ; C L_{I N D 1}^{L W D}\right.$ and $C L_{I N D 2}^{L W D} ; C L_{R O S S}^{T L D}$ and $C L_{P A C}^{T L D}$ ) for the DC, LWD and TLD sites (Fig. 4a). In these definitions, the superscript and subscript represent the starting site for clustered $\mathrm{TJ}$ and the main sector provenance, respectively. In addition, the calculation with two clusters for TDN is also shown in Fig. 4 for comparison. 
The TJ ensemble connected to a pathway for the most part of the time over the continent and then not fulfilling conditions described in Sect. 2.4, is defined as an additional cluster $C L_{A N}^{T D N}, C L_{A N}^{D C}, C L_{A N}^{T L D}$ and $C L_{A N}^{L W D}$ for TDN, DC, TLD and LWD, respectively. Almost all of the TJ used in the cluster analysis showed cyclonic curvature, reflecting the substantial influence of cyclones on air parcel paths related to snowfall (Reijmer et al. 2002). Only a subset intruding above West Antarctica and flowing over the Ross Ice Shelf towards the sites of interest had reduced curvature with respect to TJ moving poleward from the Indian or Pacific oceans.

The analyses of the clusters $C L_{I N D 1}^{L W D}$ and $C L_{I N D 2}^{L W D}$ (Fig. 4a) clearly illustrated that $L W D$ received all of its precipitation from the western Indian Ocean. $C L_{I N D 1}^{L W D}$ occurred mainly during the winter (Fig. $4 \mathrm{~b}$ ), showing mean and total precipitation values at the site that were twice as large as $C L_{I N D 2}^{L W D}$. Furthermore, its mean path was situated towards the equator and consequently showed a greater velocity approaching the site compared to the other clusters.

The DC TJ mainly came from the western Indian Ocean ( $85 \%$ of precipitation), but a small amount of moisture was also found to come from the east through the Ross Sea crossing the Transantarctic Mountains (15\%). Conversely, $C L_{P A C}^{D C}$ was characterised by $\mathrm{TJ}$ coming from the entire longitudinal arch between $150^{\circ} \mathrm{E}$ and $60^{\circ} \mathrm{W}$ and intercepting the Antarctic over Ellsworth Land and the Marie Byrd Land or Victoria Land coasts. On the other hand, $C L_{I N D}^{D C}$ members had eastward paths above the Indian Ocean following the main CPT stream, with intrusion inland over the Wilkes Land (Fig. 4a). In addition, $C L_{I N D}^{D C}$ members had a marked winter-early spring maximum frequency, whereas $C L_{P A C}^{D C}$ highlighted two peaks, the first in the early spring and the second in the fall (Fig. 4c). The TJ in $C L_{I N D}^{D C}$ brought, on average, more precipitation to the site than those of $C L_{P A C}^{D C}$, with a mean $\mathrm{SF}$ of $0.23 \pm 0.22 \mathrm{~mm}$ w.e. $\left(+12 \%\right.$ with respect to $C L_{P A C}^{D C}$ ). Reijmer et al. (2002) claimed that snowfall $\mathrm{TJ}$ at $\mathrm{DC}$ during the summer were shifted westward with respect to the winter snowfall TJ, but they always came from the Indian Ocean-Tasman Sea. This finding was apparently in contrast to our result. However, further analysis showed that our $C L_{P A C}^{D C}$ cluster is constituted by TJ coming both from the eastern Pacific through the Ross Ice Shelf (related to very low amounts of precipitation at the site, mostly below a threshold value of 0.25-mm w.e applied in Reijmer et al. (2002) for DC analysis) and some other TJ moving over the western Pacific-Tasman Sea and intruding into the continent over the Ross Sea or northern Victoria Land area (associated with greater precipitation events).

The TLD receives $50 \%$ of its total precipitation from the west (Indian Ocean), 30\% from the east (Ross Sea and
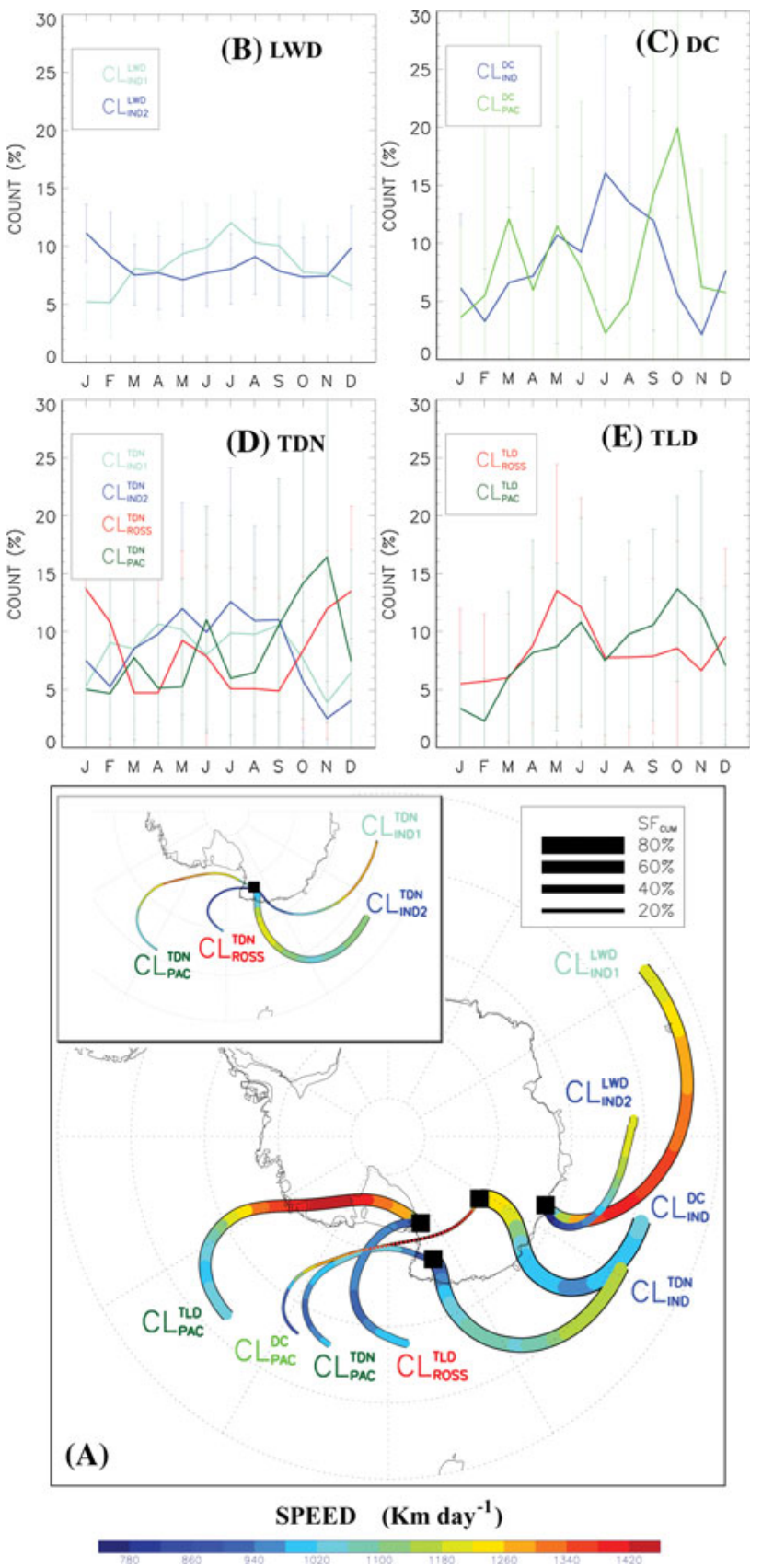

Fig. 4 a The main panel represents mean 5-day back trajectory related to two cluster divisions for the Law Dome (LWD) and Dome C (DC), Talos Dome (TND) and Taylor Dome (TLD) sites. The smaller panel is the same as main panel but shows only TDN back trajectories sampled with four clusters. The colour code and thickness of TJ lines represent the average TJ horizontal speed $\left(\mathrm{km} \mathrm{day}^{-1}\right)$ and percentage of precipitation related to each cluster respectively. Monthly mean frequency with standard deviation for cluster elements for the $\mathbf{b}$ LWD, $\mathbf{c}$ DC, $\mathbf{d}$ TDN and $\mathbf{e}$ TLD sites

Pacific Ocean) and approximately 15\% from the interior (Fig. 4a). As such, $C L_{I N D 1}^{T D N}$ and $C L_{I N D 2}^{T D N}$ came from the Indian Ocean and intruded over the eastern side of Wilkes 
Fig. 5 Hourly mean (tick lines) of pressure $(\mathbf{a} \mathrm{hPa})$, specific humidity (b $\mathrm{g} \mathrm{kg}^{-1}$ ), temperature $\left(\mathbf{c}^{\circ} \mathrm{C}\right)$ and precipitation ( $\mathbf{d}$ in $\mathrm{mm}$ w.e.) for LWD, DC TDN and TLD along back trajectory paths for cluster IND (blue lines), cluster PAC (green lines), cluster ROSS (red lines) and for all trajectories (black line). Horizontal dashed lines represent the mean time when particles started to flow over the continent with standard deviation for different clusters and specific humidity anomalies for all of the trajectories for the different clusters in panels a and $\mathrm{b}$ respectively

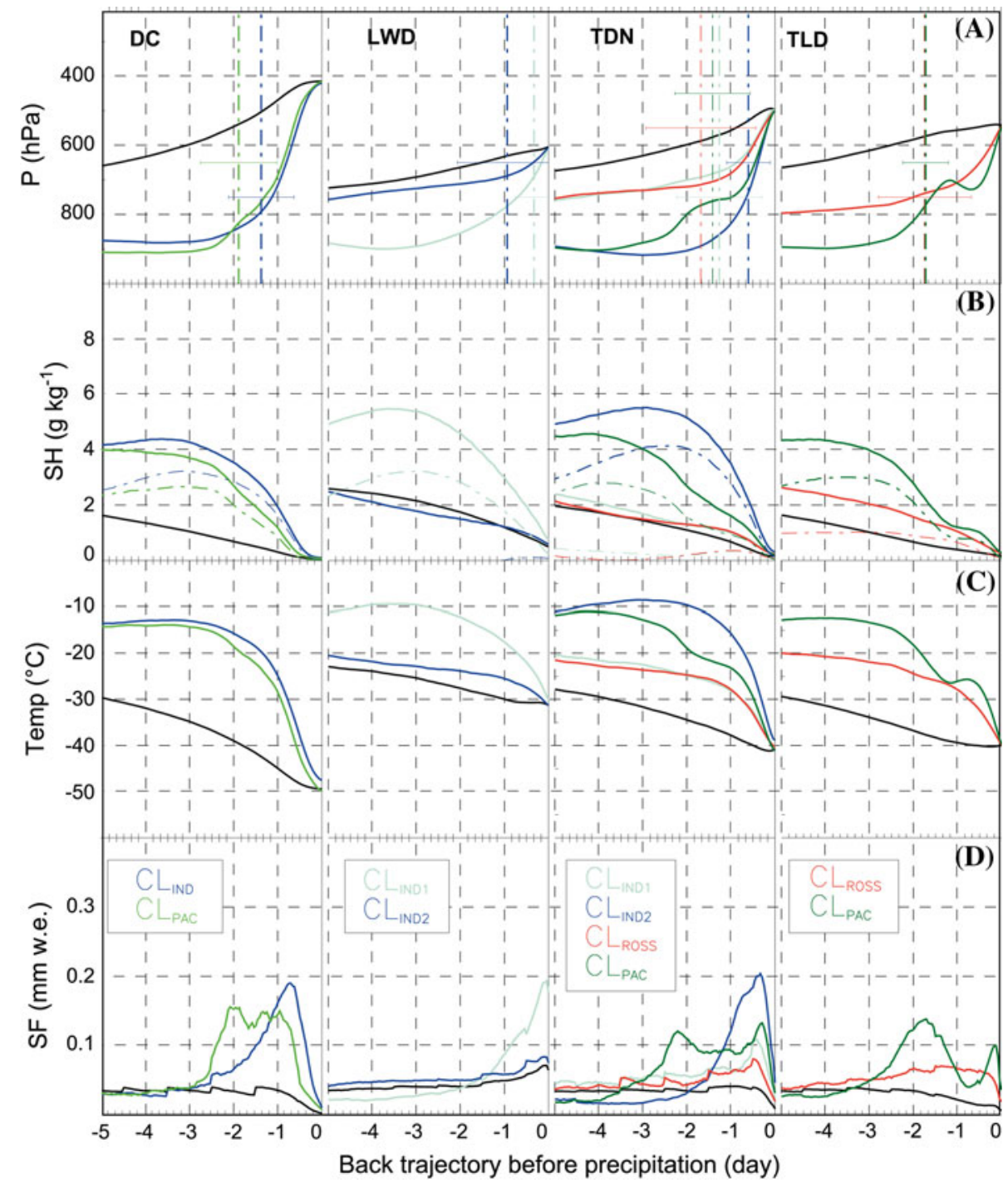

Land. $C L_{I N D 1}^{T D N}$ members showed poleward positions, on average, with respect to $C L_{I N D 2}^{T D N}$. The $C L_{R O S S}^{T D N}$ stands for TJ moving from the Ross Sea towards the site through northern Victoria Land with the smallest air mass speed during the five-day period, whereas $C L_{P A C}^{T D N}$ represents air masses coming from the western Pacific. Furthermore, the Indian Ocean clusters $\left(C L_{I N D 1}^{T D N}\right.$ and $\left.C L_{I N D 2}^{T D N}\right)$ principally occurred during the fall and winter (Fig. $4 \mathrm{~d}$ ), while $C L_{R O S S}^{T D N}$ and $C L_{P A C}^{T D N}$ occurred primarily in the summer and late fall, respectively. $C L_{I N D 2}^{T D N}$ and $C L_{R O S S}^{T D N}$-related events were, on average, the heaviest $(1.11 \pm 1.13 \mathrm{~mm}$ w.e. $)$ and the smallest $(0.46 \pm 0.50 \mathrm{~mm}$ w.e. $)$ at site, respectively.

Finally, TLD was found to receive all of its precipitation from the Pacific through the Ross Sea $\left(C L_{R O S S}^{T L D}, 35 \%\right.$ of the total SF) and the West Antarctica/Ross Ice Shelf $\left(C L_{P A C}^{T L D}\right.$, 65\%). The latter caused slightly more precipitation at the site $(0.86 \pm 0.90 \mathrm{~mm}$ w.e. $)$ than the former and exhibited an increase in its main velocity above the western Antarctic area between the second and third day. The seasonal trend displayed a $C L_{R O S S}^{T D N}$ peak in the late fall and a $C L_{R O S S}^{T D N}$ peak in the spring (Fig. 4e).

The mean thermodynamic features along the TJ path are presented in Fig. 5. Generally speaking, air parcels were lifted at the beginning of the steep Antarctic coasts with subsequent adiabatic cooling and loss of humidity through condensation (Bromwich 1988). Snowfall-related air masses travel at higher-pressure levels closer to sea level (Fig. 5a) and are therefore more likely to interact with the surface (Reijmer et al. 2002).

The cluster members from the Indian Ocean $\left(C L_{I N D}^{D C}\right.$, $C L_{I N D 1}^{L W D}$ and $\left.C L_{I N D 2}^{T D N}\right)$ were "warmer" and brought more humidity than TJ coming from the Pacific $\left(C L_{P A C}^{D C}, C L_{P A C}^{T D N}\right.$, and $C L_{P A C}^{T L D}$ ). Their moisture loads increased, on average, between 48 and $96 \mathrm{~h}$ before arrival, with differences reaching up to $1.5 \mathrm{~g} / \mathrm{kg}$ for the TDN site (Fig $5 \mathrm{~b}$, c). In agreement with these data, they showed an SF field peaking 
in the last day before arrival, with precipitation up to $0.2 \mathrm{~mm}$ w.e. On the other hand, the TJ coming from the eastern Pacific intersected the West Antarctic Ice Sheet before those arising from the Indian Ocean, between the first and second day before arrival at the site, but with higher variability. This phenomenon was due to the high elevation of the East Antarctica coast with respect to West Antarctica, where TJ have a larger area where they can intrude inland. Additionally, the precipitation along their path was up to $0.15 \mathrm{~mm}$ w.e. between the first and second days before arrival at the site. Therefore, the signature of the Ross Ice Shelf on their thermodynamic conditions was noteworthy, with a sudden increase in pressure, temperature and specific humidity when the TJ flowed down in the ice shelf "hole" $20-30 \mathrm{~h}$ before arrival to cause the subsequent precipitation event over the Transantarctic Mountains (Fig. 5d). Finally, TJ related to the Ross Sea path $\left(C L_{R O S S}^{T D N}\right.$ and $\left.C L_{R O S S}^{T L D}\right)$ displayed modest variations from mean TJ characteristic values, with small specific humidity loads and precipitation amounts along their path.

\section{Synoptic features related to snowfall}

\subsection{High- and low-frequency geopotential anomaly pattern evolution}

Figure 6 shows the composite map with time lags from -3 to +2 days $\left(M P t s^{G P}\right)$ for low- and high-frequency anomalies of GP at $500 \mathrm{hPa}$ for specific clusters. The MPts ${ }^{G P}$ were created using only snowfall events greater than 0.2 , $1.3,0.7$ and $0.5 \mathrm{~mm}$ w.e. $(40,89,63$ and $50 \%$ of the considered snowfall) for DC, LWD, TDN and TLD, respectively. The snowfall thresholds are chosen in order to obtain the best compromise between an appropriate number of considered TJ to ensure a purposeful statistics and the necessity to highlight only the most significant synoptic signals associated with the greatest precipitations phenomena. The absolute values is done following Reijmer et al. (2002) with greater threshold value for site with greater snowfall quantity in order to disregards in each of them the main signal patterns from spurious ones. Only two and one series for TDN and DC, respectively, are shown to emphasise signals that were connected to larger precipitations over interior sites. In general, the low-frequency patterns highlighted strong symmetry with respect to the Antarctic continent along $65^{\circ} \mathrm{S}$ with maximum values from +30 to $+150 \mathrm{~m}$ with respect to the zonal mean (above the Tasman Sea, eastern and western Pacific, off of the Marie Byrd Coast and above the East Antarctic Plateau), and minimum values up to $-120 \mathrm{~m}$ occurred over the Atlantic, Indian and Ross Seas. On the other hand, high-frequency $M P t s{ }^{G P}$ highlighted greater variability over the entire hemisphere, particularly in the western Pacific Ocean, Tasman Sea and eastern Indian Ocean.

Low-frequency clusters related to the Pacific Ocean $\left(C L_{P A C}^{T D N}\right.$ and $\left.C L_{P A C}^{T L D}\right)$ show an enhanced tendency to develop a wave number 3 configuration. Positive GP areas along the Pacific split with a slight enhancement of relative maxima offshore in the Bellingshausen Sea, which then developed a
Fig. 6 Mean evolution cycle $\left(M P t s^{G P}\right)$ of the 10-day lowpass filtered geopotential (filled contour, m) and 2-6-day highpass (red and black lines for positive and negative values, respectively) filtered geopotential deviation from the zonal mean at $500 \mathrm{hPa}$, calculated for $C L_{P A C}^{T D N}, C L_{I N D 2}^{T D N}$ and $C L_{I N D}^{D C}$. The high-pass filter contour is every $5 \mathrm{~m}$, whereas the low-pass filter composite is every 5 and $10 \mathrm{~m}$ for $C L_{P A C}^{T D N}$ and $C L_{I N D}$, respectively. The colour code in the ring bounding each composite represents percentage of the mean number of blocked longitudes, as calculated with the TMR method respect to the number of events
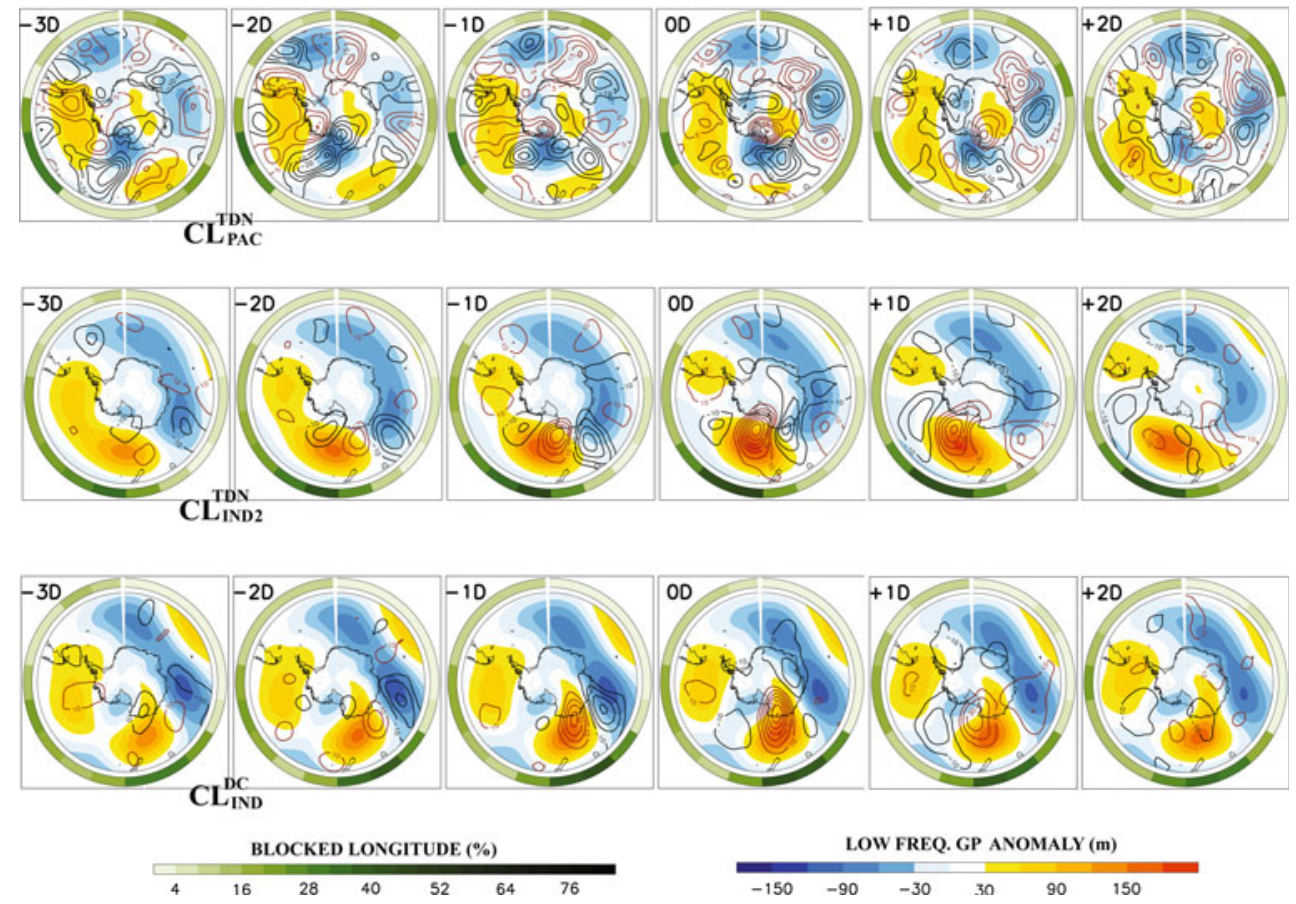
small ridge along the Marie Byrd area towards the Ross Ice Shelf during the days before an SF event. This condition, coupled with the enhanced cyclonic circulation established above the Ross Sea, allowed sea air masses to be driven from the Ross Sea and the Pacific Ocean to higher latitudes towards the Marie Byrd coast and the Ross Ice Shelf.

For $C L_{P A C}^{T D N}$ (Fig. 6), the lowered extent of ridges over Marie Byrd Land and the invariance of maximum strength over the Plateau region forced air particles to deflect their path more northward towards northern Victoria Land. For $C L_{P A C}^{T L D}$, on the other hand, the low anomalies at high frequency, even with an enhanced noise pattern (data not shown), caused it to intrude and then vanish towards the eastern Plateau region.

The clusters $C L_{I N D 1}^{T D N}, C L_{I N D 2}^{T D N}$ and (with a smoothed pattern) $C L_{R O S S}^{T D N}$ showed similar dynamic features. A division of a positive anomaly band over the Pacific, due to a rapid increase in GP maximum anomalies east of New Zealand and a progressive lowering of the eastern Pacific anomalies maxima (Fig. 6), was apparent in the low-frequency pattern. In addition, a markedly elongated maximum appeared south of New Zealand between $160^{\circ} \mathrm{E}$ and $150^{\circ} \mathrm{W}$, whereas a negative anomaly above Ross Sea progressively decreased. This correlated well with the observations of Sinclair (1996), who showed that rapidly intensified anticyclones occurring at higher latitudes than normal were most frequent in southern New Zealand, South America and Africa.

Precipitation at TDN was also found to be connected with eastward movements within the zonal flow of highfrequency perturbations. Figure 6 highlights a well-developed wave train of meridionally elongated eddies moving from the Atlantic Ocean to the Indian Ocean. This wave train moved slightly towards the equatorward for $C L_{I N D 2}^{T D N}$ (data not shown), crossing the Southern hemisphere with an enhanced 3-4 wave number. Additionally, Dell'Aquila et al. (2007) observed that wavenumber 4 accounted for most high ( $<10$ days) and low ( $>10$ days) frequency atmospheric variability in the JJA period. One day before and during the day of the event, the edge of the wave train is excited during its passage over low-frequency maxima. These conditions blocked the zonal flow and channelled wet and hot air masses towards the continent and down the passage between $160^{\circ} \mathrm{E}$ and $110^{\circ} \mathrm{E}$.

For MPts ${ }^{G P}$ of the $C L_{I N D}^{D C}$ cluster, the Tasman Sea lowfrequency maximum grew 4 days before the event offshore of the Wilkes Land coast between Tasmania and New Zealand, with development of an extensive ridge towards the continent that connected the positive anomaly over the highest part of the eastern Plateau region (Fig. 6). The ridge persisted from 2 days before to 2 days after the event and then degraded into two distinct maximum structures. In this way, wet air masses were pumped from the Indian Ocean and raised towards the most inaccessible parts of eastern Antarctica within the coupled effect of minima along Wilkes Land and the Ross Sea. With respect to the TDN cycle, there was no decrease in minimum anomaly features over the Ross Sea and ridge movement was westward, in opposition to the zonal flow. The DC case described here could be related to a symmetric oscillation configuration that was established in a high-frequency pattern with the sudden increase of GP anomalies 5 days before the event and the decreased eddy activity over the entire hemisphere, and it caused the block or even the destruction of the zonal flow. These oscillations started 3 days before the event and lasted until 3 days after, at which point the eddies were organised as a deep low with a centre over Wilkes land within two elongated highs, the former from Amundsen to Bellingshausen Seas and the latter crossing the Indian Ocean. During the first day before and the day of the event, the system had an inverse configuration with an impressive high anomaly that was meridionally elongated over the eastern Antarctic and embedded by two lows.

$C L_{P A C}^{D C}$ was a mixture of TJ flow from the eastern Pacific Ocean and the Tasman Sea, as discussed in Sect. 3.3 (data not shown). The threshold value of the precipitation intensity allowed us to use an evidence pattern similar to that of $C L_{I N D}^{D C}$, but with some differences, such the position of the low-frequency maximum being shifted slightly westward from New Zealand and the ridge intruding inland over northern Victoria Land with respect to Wilkes Land.

Features for $C L_{I N D 1}^{L W D}$ and $C L_{I N D 2}^{L W D}$ clusters (data not shown) were analogous to $C L_{I N D}^{D C}$, especially in the lowfrequency patterns, where the high maximum in the Tasman Sea and a small ridge connecting the high on the Plateau region were present in both $M P t s^{G P}$. However, neither the high- nor the low-frequency features showed the strong incitement that was apparent in the DC case. This difference was probably due to the coastal position of the site, where it was more influenced by the effect of the frequent passage of cyclone tracks than by the particular conditions related to the deflection of the zonal flow.

\subsection{Eliassen-Palm vector evolution}

The E-P flux, as given in (1), provides a diagnostic tool for both eddy behaviour and the feedback of the eddies onto the mean flow (Trenberth 1986). Figure 7 represents the mean horizontal E-P flux vectors $\left(M P t s^{E_{u}}\right)$ and divergence $\left(M P t s^{\nabla \cdot E_{u}}\right)$ of barotropic component evolution during precipitation events related to $\mathrm{TJ}$ belonging to different clusters. Large divergence (up to $2 \mathrm{~m}^{2} \mathrm{~s}^{-1} \mathrm{day}^{-1}$ ) is shown in all maps along $50^{\circ} \mathrm{S}$ in the Atlantic and in the Indian basin 


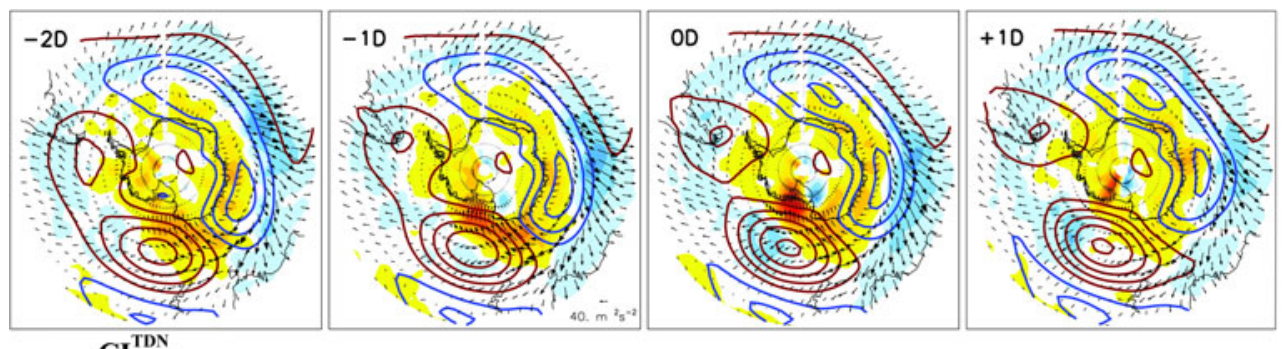

CL $\mathbf{T D N}_{\text {IND2 }}^{\mathrm{TDN}}$

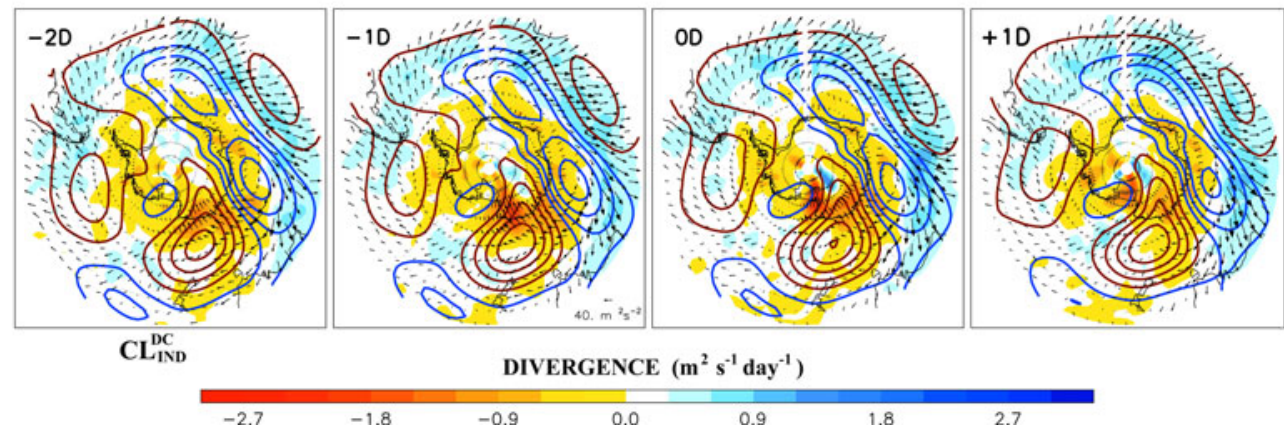

Fig. 7 Mean evolution of Eliassen-Palm vector horizontal components $\left(M P t s^{E_{u}}\right.$, black arrows, $\left.\mathrm{m}^{+2} \mathrm{~s}^{-2}\right)$ and their related divergence $\left(M P t s^{\nabla \cdot E_{u}}\right.$, filled contour, $\mathrm{m}^{2} \mathrm{~s}^{-1} \mathrm{day}^{-1}$ ) for $C L_{I N D 2}^{T D N}$ and $C L_{I N D}^{D C}$ from 2 days before to 1 day after the events. The mean evolution cycle

$\left(30^{\circ} \mathrm{W}-110^{\circ} \mathrm{E}\right)$ along the principal eddy activity area in the Southern hemisphere, with less pronounced values in the Pacific basin. Across the Antarctic continent, however, a wide area of approximately $10^{\circ}$ of latitude was present with convergence values of up to $-3 \mathrm{~m}^{2} \mathrm{~s}^{-1} \mathrm{day}^{-1}$. On the other hand, baroclinic components (not shown) exhibited negative values (convergence) in areas below $55^{\circ} \mathrm{S}$ with some scattered maximum (up to $-5 \mathrm{~m}^{2} \mathrm{~s}^{-1} \mathrm{day}^{-1}$ ) features that elongated from the Indian and western Pacific Oceans towards the Antarctic coast. In support of this observation, Trenberth (1991) showed that baroclinic effects from the poleward heat flux dominated in the winter and that eddies acted to decelerate upper tropospheric westerlies. On the other hand, barotropic effects in the upper troposphere helped to maintain the mean westerly flow by accelerating the main polar jet and maintaining the mean split in the flow near New Zealand in both the summer and the winter, even dominating the baroclinic components in the storm track in the summer.

An increase in convergence of both the barotropic and baroclinic components was clearly apparent upstream of the low-frequency, high anomaly maximum positioned from $60^{\circ} \mathrm{S}$ in the Tasman Sea-western Pacific Ocean towards the Wilkes Land coast and northern Victoria during the snowfall event cycles for $C L_{I N D}^{L W D}, C L_{I N D}^{D C}$ and $C L_{I N D}^{T D N}$ (Fig. 7). Baroclinic enhancement was positioned over the continent a few degrees poleward with respect to the barotropic ones, which fell over the sea (data not shown) $\left(\right.$ MPts $^{G P}$ ) of positive (red contour line, $\mathrm{m}$ ) and negative (blue contour line, $\mathrm{m}$ ) deviations from the zonal mean of the 10-day low-pass filtered geopotential at $500 \mathrm{hPa}$ is also reported every $10 \mathrm{~m}$

and tended to move towards the Ross Ice Shelf/Sea. At the same time, a wide divergence area developed downstream of the low-frequency maxima in the western Amundsen Sea.

\subsection{Blocking index}

Figure 8 shows the mean monthly and annual frequency blocking index obtained with the TMR method. The annual blocking frequency (as a function of $20^{\circ}$ longitudinal sectors) ranged from 4 to $20 \%$, with variability up to $10 \%$ with respect to the annual frequency value. Blocking events occurred mainly between $90^{\circ} \mathrm{E}$ and $60^{\circ} \mathrm{W}$, with peaks of $18-19 \%$ in the Pacific Ocean $\left(180^{\circ} \mathrm{W}-90^{\circ} \mathrm{W}\right)$. Low frequencies, on the other hand, were apparent between $0^{\circ} \mathrm{E}$ and $90^{\circ} \mathrm{E}$, calculation of the intra-seasonal frequency showed that maximum blocking frequencies occurred in the winter (Marques and Rao 1999). In particular, some relative maxima with values up to $27 \%$ were apparent from February to October in a large area of strong event occurrence between $160^{\circ} \mathrm{E}$ and $80^{\circ} \mathrm{W}$. Conversely, the frequency peak was confined to the $180^{\circ} \mathrm{E}-160^{\circ} \mathrm{W}$ sector during the early fall and middle winter. These findings were in accordance with Gibson (1995), who stated that the maximum blocking activity in the Tasman Sea/SW Pacific was during the fall period. Finally, other areas of high blocking frequency appeared in the eastern Pacific $\left(120^{\circ}-100^{\circ} \mathrm{W}\right)$ in agreement with studies that showed that the eastern Pacific is a 


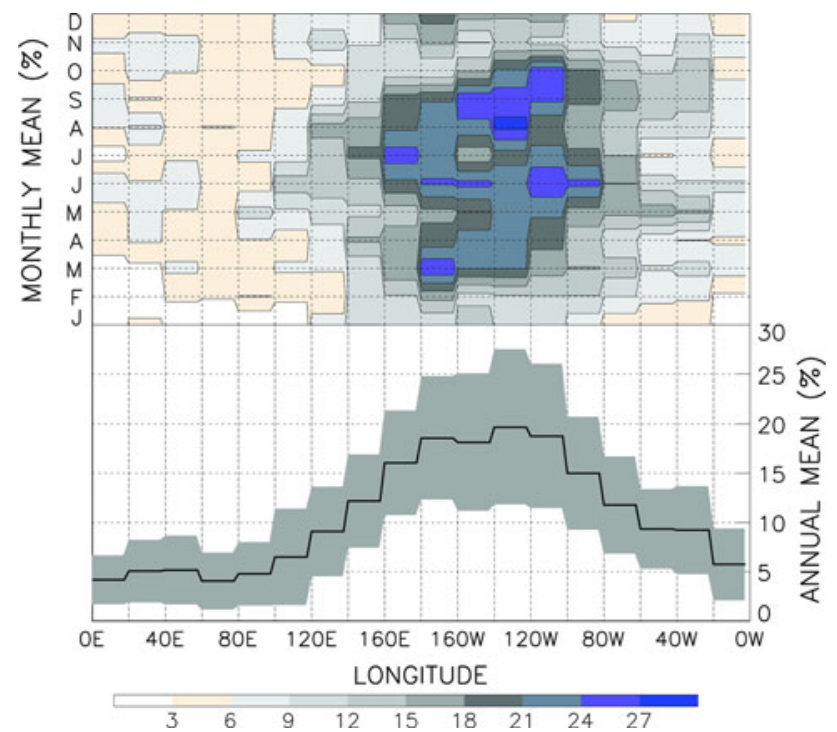

Fig. 8 Upper panel: the mean monthly frequency distribution (\%) of the blocking index as calculated by the TMR method described in Tibaldi et al. (1995) as a function of longitude. Lower panel: mean annual frequency (black line, \%) and variability (filled gray area) of the blocking index as a function of longitude

blocking region (Renwick 1998; Rutlland and Fuenzalida 1991; Sinclair 1996).

During the late spring and first part of the summer, there was a decrease in frequency along the entire hemisphere, with minima in November or December as a function of longitude (Marques and Rao 1999). Finally, the frequency slightly increased from December to January between $160^{\circ} \mathrm{E}$ and $120^{\circ} \mathrm{W}$ (Lejenäs 1984 ).

Annual and monthly high blocking event frequency trends were similar to other results found in the literature, but quantitative comparison of absolute values was difficult to accomplish due to the different methods used for objective index calculations, the ambiguity in the number of days needed to define blocking events and the great variety in model data used in various calculations. For example, the results from the TMR method were greater than those of other studies that were developed with similar objective index calculations. De Adana and Colucci (2005) and Marques and Rao (1999) proposed the highest mean annual blocking values, from 2 to $6 \%$, while blocking frequency values calculated with the TMR method seem to be in agreement with statistics that were produced by Renwick (1998) using an independent method based on an empirical orthogonal function calculation.

\section{Discussion}

The mean simulated snowfall at coastal sites (LWD, TDN, TLD; Table 1) was in reasonable agreement with measured accumulation (ratio: 80-85\%) taking into account the difference in precipitation and accumulation (spatial variability of snow accumulation and difference between sample size), but the model seriously underestimated precipitation at the plateau site DC (60\%). This underestimation could be related to clear sky precipitation that likely affected $C L_{A N}^{D C}$ but was probably negligible for $C L_{I N D}^{D C}$ snowfall.

In addition, the snowfall provenance inferred from the 5-day back trajectories was in agreement with Sodemann and Stohl (2009) for DC and LWD (Figs. 3, 9), where moisture source longitudes were shifted westward by $60^{\circ}$ with respect to a ice core location in Antarctica. Our result for TDN (35\% from the east RS+PAC and 50\% from the west IND+ATL) and TLD (45\% from east RS+PAC) explained the latitude $\left(\sim 42^{\circ} \mathrm{S}\right)$ and the longitude anomaly of moisture sources in Victoria Land highlighted by Sodemann and Stohl (2009). For the first time, our cluster analysis pointed out the remarkable differences that occurred in the western coast of the Ross Sea area where the dominant moisture provenance longitude shifted by $10-60^{\circ}$ eastward instead of westward due to the downwind westerly wind correlated to the "peculiar" atmospheric circulation of Ross Sea area. This eastward pathway of moisture was particularly relevant for TLD and somewhat less for TDN (Figs. 3, 9). Morse et al. (1999) noted that the weather at TLD was dominated by cold continental air masses and katabatic wind that arrived from the southwest. Our analysis, however, showed that most precipitation came from warm eastward flows associated with cyclones that entered the continent near Marie Byrd Land, travelled over the Ross Ice Shelf, and penetrated the Transantarctic Mountains $\left(55 \%, C L_{P A C}^{T L D}\right)$ or from northeast air flows that crossed the Ross Sea $\left(45 \% C L_{R O S S}^{T L D}\right)$.

The MPts ${ }^{G P}$ values stressed that snowfall at all four sites was connected to the interaction between low- and highfrequency anomalies in different areas of the Pacific basin at high latitudes. The moisture transport cycle for $C L_{P A C}$ and, to a lesser degree, for $C L_{R O S S}$ was not simply related to well-defined conditions but was probably the result of a coupling of synoptic and mesoscale features that were highly variable in space and time. Rockey and Braaten (1995) suggested that approximately $38 \%$ of the precipitation at McMurdo station (Southern Victoria Land; $77^{\circ} 55^{\prime} \mathrm{S}, 166^{\circ} 40^{\prime} \mathrm{E}$ ) was associated with mesoscale vortices that were formed and/or developed nearby. The high concentration of mesoscale cyclones was possible due to interactions between cold katabatic wind from the continent and warmer air flow from the sea that moved into the interior (Carrasco et al. 2003; Gallée 1996). Furthermore, Gallée (1996) found that the position of mesocyclones, in conjunction with the strong katabatic winds in Terra Nova Bay, favoured the advection of relatively mild and moist 

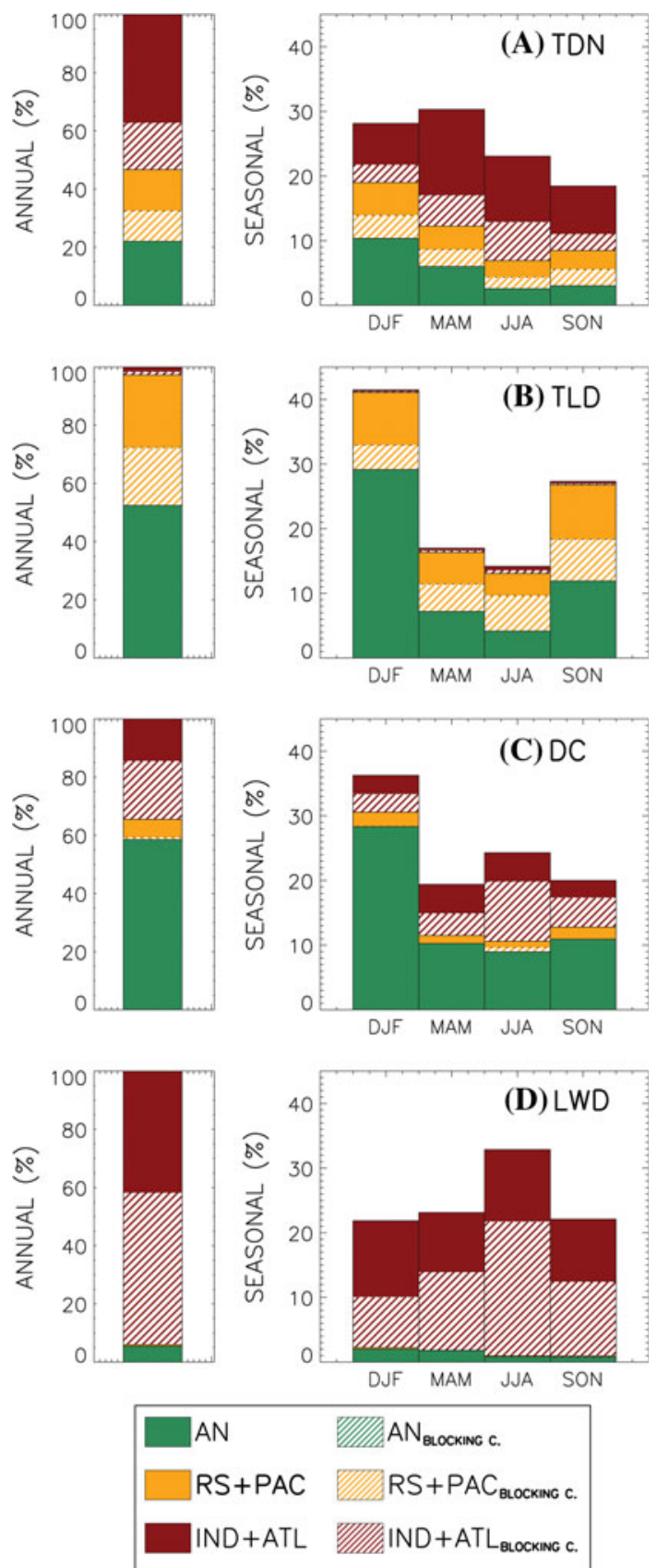

Fig. 9 Annual and seasonal percentages of snowfall related to the 5-day trajectories that spent the greatest part of their path above either the Pacific Ocean and Ross Sea (orange bars), the Indian and Atlantic Oceans (red bar) or the continent (green bar) for the a Talos Dome (TDN), b Taylor Dome (TLD), c Dome C (DC) and d Law Dome (LWD). Hatched bar represents snowfall during blocking conditions, while filled bars show snowfall not satisfying blocking conditions

maritime air (moist-air intrusion) over a long distance into the ice sheet interior with continuous clear sky precipitation. Figure 6a shows the low-frequency, high anomaly that was meridionally warped, which pumped moister air towards the Ross Ice Shelf one or 2 days before the event.
Interestingly, approximately $40 \%$ of the mesoscale cyclones that were resolved near Terra Nova Bay did not develop a well-defined cloud signature and/or cyclonic dry features, as the lack of moisture due to the Ross Ice Shelf and the presence of sea ice inhibited cloud formation, a situation most common during the winter months (Carrasco et al. 2003). This finding was confirmed by the lower moisture for TJ lying largely in the Ross Sea, as was found for those belonging to $C L_{R O S S}^{T D N}$ and $C L_{R O S S}^{T L D}$, as outlined in Fig. 5b. Although TLD is a coastal site, it received $\left(C L_{A N}^{T L D}\right)$ more than $50 \%$ of its precipitation from sources that spent most of its time over the ice surface (sea ice, ice shelf and ice sheet; Fig. 9). Because of this behaviour, TLD could be considered more similar to inland sites, such as DC $(60 \%$, $\left.C L_{A N}^{D C}\right)$, than other coastal sites like LWD $\left(5 \%, C L_{A N}^{L W D}\right)$.

TDN was an intermediate situation between TLD and DC, receiving about $20 \%$ of its precipitation from the continent $\left(C L_{A N}^{T D N}\right)$. During the summer, inland provenance of moisture at TLD and DC were two times that during the other seasons, despite significant differences in the pathways. $C L_{A N}^{T L D}$ spent most of its time over the "warmer" and "wetter" West Antarctica and Ross Ice Shelf, whereas $C L_{A N}^{D C}$ spent most of the time over the "drier" and "cooler" East Antarctica.

Snowfall related to blocking conditions occurred twice as often at LWD (40\%) than at other sites (20\% DC and TLD, 25\% TDN), and higher frequencies occurred at DC and LWD during the winter months, whereas these were more evenly distributed during the year at TDN and TLD (Fig. 9). The snowfall events occurred at core sites (LWD, DC and TDN) in connection with blocking conditions for $C L_{I N D}$ and led to warmer $\left(+2^{\circ} \mathrm{C}\right)$ and more abundant (40-50\%) snowfall with respect to no-blocking conditions. Moreover, these differences had a strong impact on snow accumulation and related isotopical temperature taking into account that blocking events $C L_{I N D}$ lead to advection of warm and moist air mainly during the winter season at DC and LWD (Fig. 9). Conversely, blocking conditions for $C L_{R O S S}$ at TLD and TDN led to colder snowfall events $\left(-1.5^{\circ} \mathrm{C}\right)$.

The snowfall pathway and seasonality were clearly recognised by the spatial variability of the chemical and isotopical composition of the snow samples collected along the ITASE traverse. The analysis of snow along the longitudinal and latitudinal transect in the Dome $\mathrm{C}$ drainage area showed that the distribution pattern was controlled not only by altitude and distance from sea but also by the circulation of the air mass in the Ross Sea and in the Wilkes Coast. In addition, chemical species concentrations were found to have higher flux and dry deposition of sea salt chemical species in Victoria Land than in Wilkes Land (Proposito et al. 2002; Becagli et al. 2004; Benassai et al. 
2005; Bertler et al. 2005). Moreover, the seasonal variation of sea salt sodium ( $\mathrm{ssNa}$ ) in snow samples from Victoria Land was very weak and not in phase with annual sea-ice cycles (Udisti et al. 1999), whereas ssNa was well marked in Wilkes Land during winter and in phase with sea-ice cycles (Becagli et al. 2004).

The isotope analysis of snow showed that snowfall in Victoria Land and in the eastern Dome $\mathrm{C}$ drainage area had more negative isotope ratios than that of Wilkes Land, particularly for the eastern area of Dome C. Additionally, the Dry Valley area exhibited negative deuterium excess values (Magand et al. 2004; Masson-Delmotte et al. 2008). The strong isotope depletion in the western Ross Sea area appears consistent with the older Antarctic age calculated from air mass by Stohl and Sodemann (2010). They found that the Ross area presented the maximum value of the mean Antarctic air mass age in the lowest $100 \mathrm{~m}$ of the atmosphere ( 9 days in the winter and 16 days in the summer). Air mass entering this region was cooled strongly and had the longest ice cover pathway from the source area. The longer permanence or older age of air mass over dry/cool ice surfaces then induced stronger distillation processes and depleted the snow of stable isotopes. The most depleted isotopes and lowest flux rates were observed from Dome C to $500 \mathrm{~km}$ eastward (Magand et al. 2004), which could be related to a "precipitation shadow" effect for air masses coming from the Indian sector (Urbini et al. 2008). This observation could also be related to the longest travel pathway and older age for air masses coming from the Pacific Ocean through West Antarctica and the Ross Sea/Ice Shelf. The observed spatial gradients in isotopical and sea salt chemical compositions of snow samples were well explained by the pathway, velocity and seasonality of snow precipitation reconstructed using ERA40. Higher flux of chemical species without a marked seasonality and isotope depletion were the result of "atypical" atmospheric circulation in the Ross Sea with high and dry cyclonic activity during the winter and snowfall during the summer. This "atypical" climate signal has a remarkable impact on the TLD record, a partial impact (25\%) for the TDN record and a negligible impact for DC (7\%). Nevertheless, TDN ice proxy records permitted the investigation of the signals of change in atmospheric circulation in the Ross Sea area and the ratio between $C L_{R O S S}^{T D N}$ and $C L_{I N D}^{T D N}$ precipitation.

Other differences between DC and TDN sites lies in the observation for $C L_{I N D}^{D C}$ and $C L_{I N D}^{T D N}$ that they were differentiated in the displacement of low-frequency maxima. Indeed, snowfall conditions for $C L_{I N D}^{T D N}$ took place when the edge of the high-frequency wave train interacted with the low-frequency maximum over the Ross Sea and Wilkes Land coast, resulting in an enhanced excitation over the land and a deceleration of southern eddy branches though friction. For the DC case, however, a deep, high ridge developed from the easterly maximum south of Australia and intruded toward the Plateau region. The significant precipitation events along the Dome $\mathrm{C}$ to Dumont d'Urville (DC-DdU) route were related to this condition because of the warm and moist air masses being conveyed deep into the western part of Wilkes Land. This finding was in line with Goodwin et al. (2003), who reported that significant differences in spatial and temporal accumulation over Wilkes Land could occur as a result of the variation in the atmospheric ridging position and circumpolar long wave structure south of New Zealand and Australia.

Field measurements of snow accumulation and temperatures found warmer and higher precipitation along the ice divide DC-DdU compared to the Talos Dome and the Southern Ocean (Magand et al. 2004; Frezzotti et al. 2007). Snow accumulation and temperature measurements presented maxima exactly along the ice divide DC-DdU; east of this line, accumulation decreased and temperature decreased significantly. The behaviour of an ice divide is driven by its accumulation rate history, its spatial pattern and the conditions at the ice sheet boundaries. Therefore, the persistence of ridging from $130^{\circ} \mathrm{E}$ to $170^{\circ} \mathrm{E}$ significantly drove the spatial pattern of snow accumulation and could be the main driver in the structure and position of the ice divide DC-DdU.

The cyclic evolution of $C L_{I N D}$ and $C L_{R O S S}$ clusters calculated for DC, TDN and LWD were related to the anomalous enhancement in the GP field in the Tasman Sea and eastern Indian Ocean during the winter. $C L_{I N D}$ could be connected with the splitting of the flow through the onset of blocking conditions at fairly high latitudes. In addition, the seasonal number of $C L_{I N D}$ cluster elements were very similar, with blocking frequencies between $150^{\circ} \mathrm{E}$ and $180^{\circ} \mathrm{E}$ and maxima in the winter (JJA). Calculation with the TMR method showed that up to 45 and $50 \%$ of the longitude of the major low-frequency high anomalies were blocked during the heaviest precipitation of $C L_{I N D}^{D C}$ and $C L_{I N D}^{T D N}$ events, respectively (Fig. $4 \mathrm{c}, \mathrm{b}$ ). $E_{u}$ diagnostics also confirmed the tendency of $C L_{I N D}$ systems to block zonal flow. Furthermore, the strong convergence of both $E_{u}$ baroclinic and barotropic components at $300 \mathrm{hPa}$ over the Ross Sea and Wilkes Land coasts suggested that transient eddies acted to decelerate westerlies near the split of the flow, maintaining blocking conditions during mean snowfall event cycles. This finding was confirmed by the calculated MPts cycle of the u anomaly from the seasonal mean (data not shown), which highlighted a persistent decrease over the area where the lowfrequency anomaly was positioned and an increase on its flank. 


\section{Conclusion}

The mean mechanism leading to snowfall events in East Antarctica were studied through the analysis of the provenance of the calculated air mass back trajectories and the dynamic conditions related to them based on ECMWF ERA 40 re-analysis data (1980-2001). The results were compared with the spatial variability in chemical and isotopical composition of snow samples collected along the ITASE traverse.

The back trajectories showed that, on an annual basis, the Atlantic-Indian and Ross-Pacific Oceans snow precipitation largely influenced Wilkes Land (80\%) and Victoria Land $(40 \%)$, respectively. The greatest influence of the Plateau sector was on an internal area near the Vostok site (80\%), an effect that decreased towards the coast along the interior. Northern Victoria Land represents the area where all of the sectors had the same influence. The three sectors displayed an intra-seasonal variability of $20 \%$ along their respective areas of influence, with the greatest variation in the summer and winter.

Moisture source longitudes were shifted by $60^{\circ}$ westward with respect to ice core location in East Antarctica (Dome C, Law Dome, and 60\% of the TJ of Talos Dome), whereas moisture source longitudes for the ice core facing the Ross Sea were located more eastward than their original longitude locations (Taylor Dome and $25 \%$ of the TJ for Talos Dome).

The Taylor Dome and part of the Talos Dome received snowfall from an "atypical" pathway (eastern instead of western), seasonality (summer instead of winter) and velocity (old air age) when compared to the other two East Antarctic cores (Dome C and Law Dome). These "atypical" characteristics were reflected in observed chemistry flux of sea salt and isotope depletion of snow samples. These differences must therefore be taken into account when the climate records of the Ross Sea area are compared with East Antarctic records. The Talos Dome as a whole received snowfall from both eastern and western pathway, which was characterised by different chemical and isotopical compositions.

Past changes in the ratio of snowfall between the two pathways could be detected in local ice core and provided information about change in mesoscale atmospheric circulation. During the Last Glacial Maximum and most of the deglaciation period, due to the presence of an ice sheet in the Ross Sea embayment (Ross Ice Sheet) and the higher elevation of West Antarctica (approximately +200/300 m), in Victoria Land the eastern precipitation from the Pacific sector via "Ross Ice Sheet" were expected to be drastically reduced with relatively increase of precipitation percentage coming from Indian Ocean.

Dynamic conditions occurring at low ( $>10$ days) and high (2-6 days) frequencies were evaluated during the mean snowfall cycle for precipitation at four sites (Talos Dome, Law Dome, Dome C and Taylor Dome). The calculation of filtered geopotential fields at $500 \mathrm{hPa}$, eddy wave-flux diagnostics and the blocking index revealed a connection between the snowfall at a site and a low-frequency large positive geopotential anomaly developing in the Tasman Sea-eastern Indian Ocean at a higher latitude $\left(60-70^{\circ} \mathrm{S}\right)$ than normal. This event would then deflect warmer and moister air towards the continent. During stronger precipitation events up to $50 \%$ of the considered cases, the atmospheric flow experienced blocking events, with transient eddies acting to decelerate westerlies in the split region area and accelerate the flow on the flanks of the low-frequency positive anomaly. The highest blocking frequencies, between $150^{\circ} \mathrm{E}$ and $180^{\circ} \mathrm{E}$, induced higher snowfall western of $140^{\circ} \mathrm{E}$ and could drive the position and structure of the ice divide between Dome C and Dumont d'Urville.

The statistical analysis here has focused on the spatial variability and seasonality of snowfall and their implication on snow accumulation and its chemical and isotopical compositions. Nonetheless, analysis of inter-annual variability using ECMWF data and comparison with highresolution ice core records or direct measurements of snowfall would further enhance our understanding of the historical mode of climate variability recorded in the Antarctic ice record and quantify the state of the Southern climate in recent history.

Acknowledgments This research was carried out as part of the framework of the Project on Glaciology of the PNRA-MIUR, and was financially supported by the PNRA Consortium through a collaboration with ENEA Roma. The Talos Dome Ice core Project (TALDICE), a joint European programme, is funded by national contributions from Italy, France, Germany, Switzerland and the United Kingdom. Primary logistical support was provided by PNRA at Talos Dome. This is TALDICE publication no 10 . We acknowledge the ice2sea project, funded by the European Commission's 7th Framework Programme through grant number 226375, ice2sea manuscript number 15 .

\section{Appendix 1: acronyms}

$\begin{array}{ll}\text { AAO } & \text { Antarctic Oscillation } \\ \text { AN } & \text { Antarctica Sector } \\ \text { ATL } & \text { Atlantic Ocean Sector } \\ \text { CPT } & \text { CircumPolar Trough } \\ \text { DC } & \text { Dome C } \\ \text { DdU } & \text { Dumont D'Urville } \\ \text { ECMWF } & \text { European Centre Medium Range Weather } \\ & \text { Forecast } \\ \text { EPICA } & \text { European Project for Ice Coring in } \\ & \text { Antarctica } \\ \text { ERA } & \text { European Re-Analysis } \\ \text { FLEXPART } & \text { Lagrangian Particle Dispersion Model }\end{array}$




$\begin{array}{ll}\text { HYSPLIT } & \begin{array}{l}\text { Hybrid Single-Particle Lagrangian } \\ \text { Integrated Trajectory }\end{array} \\ \text { IND } & \quad \text { Indian Ocean Sector } \\ \text { LWD } & \text { Law Dome } \\ \text { NOAA } & \begin{array}{l}\text { National Oceanic and Atmospheric } \\ \text { Administration }\end{array} \\ \text { PO } & \quad \text { Pacific Ocean Sector } \\ \text { PSA } & \quad \text { Pacific South American } \\ \text { RS } & \quad \text { Ross Sea Sector } \\ \text { TALDICE } & \quad \text { TAlos Dome Ice CorE } \\ \text { TDN } & \quad \text { Talos Dome } \\ \text { TLD } & \quad \text { Taylor Dome } \\ \text { VSK } & \quad \text { Vostok } \\ & \\ & \\ E_{u} & \text { Eliassen-Palm flux vector } \\ \text { f } & \text { Coriolis parameter } \\ G P & \text { Geopotential fields } \\ G P_{A N O M} & \text { Anomaly in GP field with respect to the long } \\ & \text { term annual mean } \\ R H_{w} & \text { Relative Humidity with respect to water } \\ \text { SF } & \text { Precipitation } \\ T & \text { Temperature } \\ u & \text { Zonal wind component } \\ v & \text { Meridional wind component } \\ w & \text { Vertical wind component } \\ \phi & \text { Latitude } \\ \sigma & \text { Static stability } \\ & \end{array}$

CL Cluster group

$C L_{I N D 1}^{T D N} \quad$ Cluster for TJ starting from TDN and coming from high latitude over the Indian Ocean Sector $C L_{I N D 2}^{T D N}$ Cluster for TJ starting from TDN and coming from low latitude over the Indian Ocean Sector $C L_{R O S S}^{T D N}$ Cluster for TJ starting from TDN and coming from the Ross Sea Sector

$C L_{P A C}^{T D N} \quad$ Cluster for TJ starting from TDN and coming from the Pacific Ocean Sector

$C L_{I N D}^{D C} \quad$ Cluster for $\mathrm{TJ}$ starting from $\mathrm{DC}$ and coming from the Indian Ocean Sector

$C L_{P A C}^{D C} \quad$ Cluster for TJ starting from DC and coming from the Pacific Ocean Sector

$C L_{I N D 1}^{L W D} \quad$ Cluster for TJ starting from LWD and coming from high latitude over the Indian Ocean Sector

$C L_{I N D 2}^{L W D}$ Cluster for TJ starting from LWD and coming from low latitude over the Indian Ocean Sector

$C L_{R O S S}^{T L D}$ Cluster for TJ starting from TLD and coming from the Ross Sea Sector

$C L_{P A C}^{T L D} \quad$ Cluster for TJ starting from TLD and coming from the Pacific Ocean Sector
MPts
$M P t s{ }^{G P}$
Map time series
$M P t s^{E_{u}}$
Map time series for Geopotential field
$M P t S^{\nabla \cdot E_{u}}$
Map time series for E-P flux vector
Map time series for E-P flux vector divergence

TJ

TMR Blocking index as defined in Tibaldi et al.

(1995)

\section{References}

Barbante C, Fischer H, Masson-Delmotte V, Waelbroeck C, Wolff EW (2010) Climate of the last million years: new insights from EPICA and other records. Quat Sc Rev 29:1-7. doi: 10.1016/jquascirev200911025

Becagli S, Proposito M, Benassai S, Flora O, Genoni L, Gragnani R, Largiuni O, Pili SL, Severi M, Stenni B, Traversi R, Udisti R, Frezzotti M (2004) Chemical and isotopic snow variability in East Antarctica along the 2001/02 ITASE traverse. Ann Glaciol 39:473-482

Benassai S, Becagli S, Gragnani R, Magand O, Proposito M, Fattori I, Traversi R, Udisti R (2005) Sea spray deposition in Antarctic coastal and plateau areas from ITASE traverses. Ann Glaciol 41:32-40

Bertler N, Mayewski PA, Aristarain A, Barrett P, Becagli S, Bernardo R, Bo S, Xiao C, Curran M, Qin D, Dixon D, Ferron F, Fischer H, Frey M, Frezzotti M, Fundel F, Genthon C, Gragnani R, Hamilton G, Handley M, Hong S, Isaksson E, Kang J, Ren J, Kamiyama K, Kanamori S, Karkas E, Karlof L, Kaspari S, Kreutz K, Kurbatov A, Meyerson E, Ming Y, Zhang M, Motoyama H, Mulvaney R, Oerter H, Osterberg E, Proposito M, Pyne A, Ruth U, Simoes J, Smith B, Sneed S, Teinila K, Traufetter F, Udisti R, Virkkula A, Watanabe O, Williamson B, Winther JG, Li Y, Wolff E, Li Z, Zielinski A (2005) Snow chemistry across Antarctica. Ann Glaciol 41:167-179

Bromwich DH (1988) Snowfall in high southern latitudes. Rev Geophys 26:149-168

Bromwich DH, Wang SH, Monaghan AJ (2002) ERA-40 representation of the artic atmosphere moisture budget. Proceedings in ECMWF Workshop on Re-analysis, 5-9 November 2001. ERA40 project report series no 3 reading, England, pp 287-298

Bromwich DH, Fogt RL, Hodges KE, Walsh JE (2007) A tropospheric assessment of the ERA-40, NCEP, and JRA-25 global reanalyses in the polar regions. J Geophys Res 112:D10111. doi: 10.1029/2006JD007859

Carrasco JF, Bromwich DH, Monaghan AJ (2003) Distribution and characteristics of mesoscale cyclones in the Antarctic: Ross Sea eastward to the Weddell Sea. Mon Wea Rev 131:289-301

Ciais P, Jouzel J (1994) Deuterium and oxygen 18 in precipitation: isotopic model, including mixed cloud processes. J Geophys Res 99(D8):16793-16803. doi:10.1029/94JD00412

Cuff TJ, Cai M (1995) Interaction between the low and highfrequency transients in the southern hemisphere winter circulation. Tellus A 47:331-350

D’Andrea F, Tibaldi S, Blackburn M, Boer G, Déqué M, Dix MR, Dugas B, Ferranti L, Iwasaki T, Kitoh A, Pope V, Randall D, Roeckner E, Straus D, Stern W, van den Dool H, Williamson D (1998) Northern hemisphere atmospheric blocking as simulated 
by 15 atmospheric general circulation models in the period 1979-1988. Clim Dyn 14:385-407

De Adana FJS, Colucci S (2005) Southern hemisphere blocking onsets associated with upper-tropospheric divergence anomalies. J Atmos Sci 62:1614-1625

Delaygue G, Masson V, Jouzel J, Koster RD, Healy RJ (2000) The origin of Antarctic precipitation: a modelling approach. Tellus B 52(1):19-36

Dell'Aquila A, Ruti PM, Calmanti S, Lucarini V (2007) Southern hemisphere midlatitude atmospheric variability of the NCEPNCAR and ECMWF reanalyses. J Geophys Res 112:D08106. doi:10.1029/2006JD007376

Delmotte M, Masson V, Jouzel J, Morgan VI (2000) A seasonal deuterium excess signal at Law Dome, coastal eastern Antarctica: a southern ocean signature. J Geophys Res 105:7187-7197. doi:10.1029/1999JD901085

Dole RM (1986) Persistent anomalies of the extratropical Northern hemisphere wintertime circulation: structure. Mon Wea Rev 114:178-207

Draxler RR (2003) Evaluation of an ensemble dispersion calculation. J Appl Meteorol 42:308-317

Eisen O, Frezzotti M, Genthon C, Isaksson E, Magand O, van den Broeke M, Dixon DA, Ekaykin A, Holmlund P, Kameda T, Karlof L, Kaspari S, Lipenkov VY, Oerter H, Takahashi S, Vaughan DG (2008) Ground-based measurements of spatial and temporal variability of snow accumulation in East Antarctica. Rev Geophys 46:1-39. doi:10.1029/2006RG000218

Everitt BS (1993) Cluster analysis. Halsted Press, New York. ISBN 0470-22043-0

Frederiksen JS, Frederiksen CS (1993) Southern hemisphere storm tracks, blocking, and low-frequency anomalies in a primitive equation model. J Atmos Sci 50:3148-3163

Frezzotti M, Bitelli G, de Michelis P, Deponti A, Forieri A, Gandolfi S, Maggi V, Mancini F, Rémy F, Tabacco IE, Urbini S, Vittuari L, Zirizzotti A (2004) Geophysical survey at Talos Dome (East Antarctica): the search for a new deep-drilling site. Ann Glaciol 39:423-432

Frezzotti M, Pourchet M, Flora O, Gandolfi S, Gay M, Urbini S, Vincent C, Becagli S, Gragnani R, Proposito M, Severi M, Traversi R, Udisti R, Fily M (2005) Spatial and temporal variability of snow accumulation in East Antarctica from traverse data. J Glaciol 51:113-124

Frezzotti M, Urbini S, Proposito M, Scarchilli C, Gandolfi S (2007) Spatial and temporal variability of surface mass balance near Talos Dome, East Antartica. J Geophys Res 112:F02032. doi: 10.1029/2006JF000638

Gallée H (1996) Mesoscale atmospheric circulation over the southwestern Ross Sea sector, Antarctica. J Appl Meteor 35:11291141

Genthon C (2002) Climate and surface mass balance of the polar ice sheets in ERA40/ERA15. ECMWF re-analysis project report series 3:299-316

Gibson TT (1995) Atmospheric blocking in the Southern Hemisphere 1982-1992. In: Proceedings of the APOC and AMOS joint conference Lorne Australia Australian meteorological and oceanographic society 40

Goodwin I, de Angelis M, Pook M, Young NW (2003) Snow accumulation variability in Wilkes Land, East Antarctica, and the relationship to atmospheric ridging in the $130^{\circ}-170^{\circ} \mathrm{E}$ since 1930. J Geophys Res 108(D21):4673. doi:10.1029/2002JD002995

Helsen MM, van de Wal RSW, van den Broeke MR, MassonDelmotte V, Meijer HAJ, Scheele MP, Werner M (2007) Modeling the isotopic composition of Antarctic snow using backward trajectories: Simulation of snow pit records. J Geophys Res 111:D15109. doi:10.1029/2005JD006524
Jouzel J, Vimeux F, Carillon N, Delaygue G, Hoffmann G, MassonDelmotte V, Parrenin F (2003) Magnitude of the isotopetemperature scaling for interpretation of central Antarctic ice cores. J Geophys Res 108:4361. doi:10.1029/2002JD002677

Jouzel J, Masson-Delmotte V, Cattani O, Dreyfus G, Falourd S, Hoffmann G, Minster B, Nouet J, Barnola JM, Chappellaz J, Fischer H, Gallet JC, Johnsen S, Leuenberger M, Loulergue L, Luethi D, Oerter H, Parrenin F, Raisbeck G, Raynaud D, Schilt A, Schwander J, Selmo E, Souchez R, Spahni R, Stauffer B, Steffensen JP, Stenni B, Stocker TF, Tison JL, Werner M, Wolff EW (2007) Orbital and millennial Antarctic climate variability over the past 800, 000 years. Science 317:793-796. doi: $10.1126 /$ science. 1141038

King JC, Turner J (1997) Antarctic meteorology and climatology. Cambridge University Press, Cambridge, UK, p 409

Kottmeier C, Fay B (1998) Trajectories in the Antarctic lower troposphere. J Geophys Res 103:10947-10959

Lejenäs H (1984) Characteristics of southern hemisphere blocking as determined from a long time series of observational data. Q J Roy Meteor Soc 110:967-979

Magand O, Frezzotti M, Pourchet M, Stenni B, Genoni L, Fily M (2004) Climate variability along latitudinal and longitudinal transects in East Antarctica. Ann Glaciol 39:351-358

Marques RFC, Rao VB (1999) A diagnosis of a long-lasting blocking event over the southeast Pacific Ocean. Mon Wea Rev 127:1761-1775

Marques RFC, Rao VB (2000) Interannual variations of blocking in the Southern hemisphere and their energetics. J Geophys Res 105:4625-4636

Massom RA, Pook MJ, Comiso JC, Adams N, Turner J, LachlanCope T, Gibson T (2004) Precipitation over the interior East Antarctic ice Sheet related to midlatitude blocking-high activity. J Climate 17:1914-1928

Masson-Delmotte V, Delmotte M, Morgan V, Etheridge D, van Ommen T, Tartarin S, Hoffmann G (2003) Recent southern Indian ocean climate variability inferred from a Law Dome ice core: new insights for the interpretation of coastal Antarctic isotopic records. Clim Dyn 21:153-166. doi:10.1007/s00382003-03219

Masson-Delmotte V, Hou S, Ekaykin A, Jouzel J, Aristarain A, Bernardo RT, Bromwich DH, Cattani O, Delmotte M, Falourd S, Frezzotti M, Gallée H, Genoni L, Isaksson E, Landais A, Helsen MM, Hoffmann G, Lopez J, Morgan V, Motoyama H, Noone D, Oerter H, Petit JR, Royer A, Uemura R, Schmidt GA, Schlosser E, Simões JC, Steig EJ, Stenni B, Stiévenard M, van den Broeke MR, van de Wal RSW, van de Berg WJ, Vimeux F, White JWC (2008) A review of Antarctic surface snow isotopic composition: observations, atmospheric circulation and isotopic modelling. J Climate 21:3359-3387. doi:10.1175/2007JCLI2139.1

McMorrow AJ, Curran MAJ, van Ommen TD, Morgan VI, Allison I (2002) Features of meteorological events preserved in a highresolution Law Dome (East Antarctica) snow pit. Ann Glaciol 35:463-470

Monaghan AJ, Bromwich DH, Fogt RL, Wang S, Mayewski PA, Dixon DA, Ekaykin A, Frezzotti M, Goodwin I, Isaksson E, Kaspari SD, Morgan VI, Oerter H, Van Ommen TD, Van der Veen CJ, Wen J (2006) Insignificant change in Antarctic snowfall since the international geophysical year. Science 313:827-831. doi:10.1126/science.1128243

Morgan VI, Wookey CW, Li J, van Ommen TD, Skinner W, Fitzpatrick MF (1997) Site information and initial results from deep ice drilling on Law Dome, Antarctica. J Glaciol 43:3-10

Morse DL, Waddington ED, Marshall HP, Neumann TA, Steig EJ, Dibb JE, Winebrenner DP, Arthern RJ (1999) Accumulation rate measurements at Taylor Dome, East Antarctica: techniques and 
strategies for mass balance measurements in polar environments. Geograf Ann 81A:683-694

Noone D, Simmonds I (2002) Annular variations in moisture transport mechanisms and the abundance of $\delta^{18} \mathrm{O}$ in Antarctic snow. J Geophys Res 107(24):4742. doi:10.1029/2002JD002262

Noone D, Turner J, Mulvaney R (1999) Atmospheric signals and characteristics of accumulation in Dronning Maud Land, Antarctica. J Geophys Res 104:19191-19211

Proposito M, Becagli S, Castellano E, Flora O, Gragnani R, Stenni B, Traversi R, Udisti R, Frezzotti M (2002) Chemical and isotopic snow variability along the 1998 ITASE traverse from Terra Nova Bay to Dome C (East-Antarctica). Ann Glaciol 35:187-194

Reijmer CH, Van den Broecke MR, Scheele MP (2002) Air parcel trajectories and snowfall related to five deep drilling locations in Antarctica based on the ERA-15 dataset. J Climate 15:19571968

Renwick JA (1998) ENSO-related variability in the frequency of South Pacific blocking. Mon Wea Rev 144:3117-3123

Robertson AW, Mechoso CR (2003) Circulation regimes and lowfrequency oscillations in the South Pacific sector. Mon Wea Rev 131:1566-1576

Rockey CC, Braaten DA (1995) Characterization of polar cyclonic activity and relationship to observed snowfall events at McMurdo station, Antarctica. Preprints, 4th conference on polar meteorology and oceanography, Dallas, TX. Amer Meteor Soc 244-245

Rutlland J, Fuenzalida H (1991) Synoptic aspects of the central chile rainfall associated with Southern oscillation. Int J Climatol 11:63-76

Scarchilli C, Frezzotti M, Grigioni P, De Silvestri L, Agnoletto L, Dolci S (2010) Extraordinary blowing snow transport events in East Antarctica. Clim Dyn 34:1195-1206. doi:10.1007/s00382009-0601-0

Schlosser E, Oerter H, Masson-Delmotte V, Reijmer C (2008) Atmospheric influence on the deuterium excess signal in polar firn: implications for ice-core interpretation. J Glaciol 54:117124

Sime LC, Wolff EW, Oliver KIC, Tindall JC (2009) Evidence for warmer interglacials in East Antarctic ice cores. Nature 462:342-345. doi:10.1038/nature08564

Simmonds I, Keay K, Lim EP (2003) Synoptic activity in the seas around Antarctica. Mon Wea Rev 131:272-288

Sinclair MRA (1996) Climatology of anticyclones and blocking for the Southern hemisphere. Mon Wea Rev 124:245-263

Sodemann H, Stohl A (2009) Asymmetries in the moisture origin of Antarctic precipitation. Geophys Res Lett 36:L22803. doi: 10.1029/2009GL040242

Steig EJ, Morse DL, Waddington ED, Stuiver M, Grootes PM, Mayewski PA, Twickler MS, Whitlow SI (2000) Wisconsinan and Holocene climate history from an ice core at Taylor Dome, Western Ross Embayment, Antarctica. Geograf Ann 82:213-235

Stenni B, Buiron D, Frezzotti M, Albani S, Barbante C, Bard E, Barnola JM, Baroni M, Baumgartner M, Bonazza M, Capron E, Castellano E, Chappellaz J, Delmonte B, Falourd S, Genoni L, Iacumin P, Jouzel J, Kipfstuhl S, Landais A, Lemieux-Dudon B, Maggi V, Masson-Delmotte V, Mazzola C, Minster B, Montagnat M, Mulvaney R, Narcisi B, Oerter H, Parrenin F, Petit JR, Ritz C, Scarchilli C, Schilt A, Schüpbach S, Schwander J, Selmo E, Severi M, Stocker TF, Udisti R (2010) Expression of the bipolar seesaw in Antarctic climate records during the last deglaciation. Nature Geoscience (in press). doi:10.1038/ NGEO1026

Stenni B, Proposito M, Gragnani R, Flora O, Jouzel J, Falourd S, Frezzotti M (2002) Eight centuries of volcanic signal and climate change at Talos Dome (East Antarctica). J Geophys Res 107:1-14. doi:10.1029/2000JD000317
Stohl A, Sodemann H (2010) Characteristics of atmospheric transport into the Antarctic troposphere. J Geophys Res 115:D02305. doi: 10.1029/2009JD012536

Stohl A, Wotawa G, Siebert P, Kromp-Kolb H (1995) Interpolation errors in wind fields as a function of spatial and temporal resolution and their impact on different types of kinematic trajectories. J Appl Meteor 34:2149-2165

Stohl A, Forster C, Frank A, Seibert P, Wotawa G (2005) Technical note: the Lagrangian particle dispersion model FLEXPART version 6.2. Atmos Chem Phys 5:2461-2474

Suzuki K, Yamanouchi T, Motoyama H (2008) Moisture transport to Syowa and Dome Fuji stations in Antarctica. J Geophys Res 113:D24114. doi:10.1029/2008JD009794

Thomas ER, Bracegirdle TJ (2009) Improving ice core interpretation using in situ and reanalysis data. J Geophys Res 114:D20116. doi:10.1029/2009JD012263

Tibaldi S, Tosi E, Navarra A, Pedulli L (1994) Northern and Southern Hemisphere seasonal variability of blocking frequency and predictability. Mon Wea Rev 122:1971-2003

Tibaldi S, Ruti P, Tosi E, Maruca M (1995) Operational predictability of winter blocking at ECMWF-an update. Ann Geophys 13:305-317

Tietäväinen H, Vihma T (2008) Atmospheric moisture budget over Antarctica and the Southern ocean based on the ERA-40 reanalysis. Int J Climatol 28:1977-1995. doi:10.1002/joc.1684

Trenberth KE (1986) An assessment of the impact of transient eddies on the zonal flow during a blocking episode using localized Eliassen-Palm flux diagnostics. J Atmos Sci 43:2070-2087

Trenberth KE (1991) Storm track in the southern hemisphere. J Atmos Sci 48:2159-2178

Trenberth KE, Mo KC (1985) Blocking in the southern hemisphere. Mon Wea Rev 113:3-21

Turner J, Colwell SR, Marshall GJ, Lachlan-Cope TA, Carleton AM, Jones PD, Lagun V, Reid PA, Iagovkina S (2005) Antarctic climate change during the last 50 years. Int $\mathrm{J}$ Climatol 25:279-294

Udisti R, Becagli S, Castellano E, Traversi R, Vermigli S, Piccardi G (1999) Sea-spray and marine biogenic seasonal contribution to snow composition at Terra Nova Bay, Antarctica. Ann Glaciol 29:77-83

Uppala SM, Kållberg PW, Simmmons AJ, Andrea U, da Costa Bechtold V, Fiorino M, Gibson JK, Haseler J, Hernandez A, Kelly GA, Li X, Onogi K, Saarinen S, Sokka N, Allan RP, Andersson E, Arpe K, Balmaseda MA, Beljaars ACM, Van de Berg L, Bidlot J, Bormann N, Caires S, Chevallier F, Dethof A, Dragosavac M, Fisher M, Fuentes M, Hagemann S, Hólm E, Hoskin BJ, Isaken L, Janssen PAEM, Jenne R, McNally AP, Mahfouf J-F, Morcrette J-J, Rayner NA, Saunders RW, Simon P, Sterl A, Trenberth KE, Untch A, Vasiljevic D, Viterbo P, Woollen J (2005) The ERA-40 re-analysis. Q J Roy Meteor Soc 131:2961-3012

Urbini S, Frezzotti M, Gandolfi S, Vincent C, Scarchilli C, Vittuari L, Fily M (2008) Historical behaviour of Dome C and Talos Dome (East Antarctica) revealed by snow accumulation and ice velocity measurements. Glob Planet Change 60:576-588. doi: 10.1016/j.gloplacha.2007.08.002

Van de Berg WJ, van den Broeke MR, van Meijgaard E, Reijmer CH (2006) Reassessment of the Antarctic surface mass balance using calibrated output of a regional atmospheric climate model. J Geophys Res 111:D11104. doi:10.1029/2005JD006495

Werner M, Heimann M, Hoffmann G (2001) Isotopic composition and origin of polar precipitation in present and glacial climate simulations. Tellus B 52:53-71. doi:10.1034/j.1600-0889. 2001.01154 